Cochrane Database of Systematic Reviews

\title{
Oral 5-aminosalicylic acid for maintenance of medically-induced remission in Crohn's disease (Review)
}

Akobeng AK, Zhang D, Gordon M, MacDonald JK

Akobeng AK, Zhang D, Gordon M, MacDonald JK.

Oral 5-aminosalicylic acid for maintenance of medically-induced remission in Crohn's disease.

Cochrane Database of Systematic Reviews 2016, Issue 9. Art. No.: CD003715.

DOI: 10.1002/14651858.CD003715.pub3.

www.cochranelibrary.com 
TABLE OF CONTENTS

HEADER 1

ABSTRACT

PLAIN LANGUAGE SUMMARY ....

SUMMARY OF FINDINGS

BACKGROUND

OBJECTIVES

METHODS

RESULTS

Figure 1.

Figure 2.

Figure 3.

Figure 4.

Figure 5.

DISCUSSION

AUTHORS' CONCLUSIONS

ACKNOWLEDGEMENTS

REFERENCES

CHARACTERISTICS OF STUDIES

DATA AND ANALYSES

Analysis 1.1. Comparison 15-ASA compared to placebo, Outcome 1 Relapse, drop-outs classed as relapse, grouped by length of follow-up.

Analysis 1.2. Comparison 15-ASA compared to placebo, Outcome 2 Sensitivity analysis - Relapse, drop-outs classed as relapse, grouped by length of follow-up, random effects.

Analysis 1.3. Comparison 15-ASA compared to placebo, Outcome 3 Sensitivity analysis - Relapse, drop-outs ignored, grouped by length of follow-up.

Analysis 1.4. Comparison 15-ASA compared to placebo, Outcome 4 Sensitivity analysis - Relapse, drop-outs ignored, grouped by length of follow-up, random effects.

Analysis 1.5. Comparison 15-ASA compared to placebo, Outcome 5 Adverse events.

Analysis 1.6. Comparison 15-ASA compared to placebo, Outcome 6 Withdrawals due to adverse events.

Analysis 1.7. Comparison 15-ASA compared to placebo, Outcome 7 Serious adverse events.

Analysis 1.8. Comparison 15-ASA compared to placebo, Outcome 8 Relapse, drop-outs classed as relapse, grouped by length

of follow-up.

ADDITIONAL TABLES

APPENDICES

WHAT'S NEW

DECLARATIONS OF INTEREST

DIFFERENCES BETWEEN PROTOCOL AND REVIEW

INDEX TERMS 
[Intervention Review]

\section{Oral 5-aminosalicylic acid for maintenance of medically-induced remission in Crohn's disease}

Anthony K Akobeng1,2, Dongni Zhang ${ }^{3}$, Morris Gordon ${ }^{4}$, John K MacDonald5

1Sidra Medical \& Research Center, Doha, Qatar. ${ }^{2}$ Weill Cornell Medical College, Doha, Qatar. ${ }^{3}$ Schulich School of Medicine \& Dentistry, University of Western Ontario, London, Canada. ${ }^{4}$ School of Medicine and Dentistry, University of Central Lancashire, Preston, UK.

${ }^{5}$ Cochrane IBD Group, Robarts Clinical Trials, London, Canada

Contact address: Anthony K Akobeng, Sidra Medical \& Research Center, PO Box 26999, Doha, Qatar. aakobeng@sidra.org, akobeng@aol.com.

Editorial group: Cochrane IBD Group.

Publication status and date: New search for studies and content updated (no change to conclusions), published in Issue 9, 2016.

Citation: Akobeng AK, Zhang D, Gordon M, MacDonald JK. Oral 5-aminosalicylic acid for maintenance of medically-induced remission in Crohn's disease. Cochrane Database of Systematic Reviews 2016, Issue 9. Art. No.: CD003715. DOI: 10.1002/14651858.CD003715.pub3.

Copyright @ 2016 The Cochrane Collaboration. Published by John Wiley \& Sons, Ltd.

\section{A B S T R A C T}

\section{Background}

The prevention of relapse is a major issue in the management of Crohn's disease. Corticosteroids, the mainstay of treatment of acute exacerbations, are not effective for maintenance of remission and its chronic use is limited by numerous adverse events. Randomised controlled trials assessing the efficacy of oral 5-aminosalicylic acid (5-ASA) agents for maintenance of medically-induced remission in Crohn's disease have produced conflicting results.

\section{Objectives}

To conduct a systematic review to evaluate the efficacy and safety of oral 5-ASA agents for the maintenance of medically-induced remission in Crohn's disease.

\section{Search methods}

We searched MEDLINE, EMBASE, CENTRAL and the IBD Group Specialized Register from inception to 8 June 2016. We also searched reference lists and conference proceedings.

\section{Selection criteria}

We included randomised controlled trials that compared oral 5-ASA agents to either placebo or sulphasalazine in patients with quiescent Crohn's disease. The trials had to have a treatment duration of at least six months.

\section{Data collection and analysis}

Two authors independently extracted data and performed the risk of bias assessment. Any disagreements were resolved by discussion and consensus. The primary outcome measure was the occurrence of relapse as defined by the primary studies. Secondary outcomes included time to relapse, adverse events, withdrawal due to adverse events and serious adverse events. We calculated the pooled risk ratio (RR) and corresponding $95 \%$ confidence interval $(95 \% \mathrm{Cl})$ using a fixed-effect model. All data were analysed on an intention-to-treat basis and dropouts were considered to be relapses. Sensitivity analyses included an available case analysis where drop-outs were ignored and using a random-effects model. We evaluated the overall quality of the evidence supporting the outcomes using the GRADE criteria.

\section{Main results}

Twelve studies (2146 participants) that compared 5-ASA to placebo were included. We did not identify any studies that compared sulphasalazine to placebo. Seven studies were judged to be at low risk of bias. The other studies were judged to have an unclear risk of 
bias for various items due to insufficient details to allow for a judgement. There was no statistically significant difference in relapse rates at 12 months. Fifty-three per cent (526/998) of 5-ASA patients (dose $1.6 \mathrm{~g}$ to $4 \mathrm{~g} /$ day) relapsed at 12 months compared to 54\% (544/1016) of placebo patients (RR $0.98,95 \% \mathrm{Cl} 0.91$ to $1.07 ; 11$ studies; 2014 patients; moderate-quality evidence). Sensitivity analyses based on an available case analysis and a random-effects model had no impact on the results. One study found no difference in relapse rates at 24 months. Fifty-four per cent (31/57) of 5-ASA patients (dose $2 \mathrm{~g} /$ day) relapsed at 24 months compared to 58\% (36/62) of placebo patients (RR $0.94,95 \% \mathrm{Cl} 0.68$ to $1.29,119$ patients; low-quality evidence). One paediatric study found no statistically significant difference in relapse rates at 12 months. Sixty-two per cent (29/47) of paediatric 5-ASA patients (dose $50 \mathrm{mg} / \mathrm{kg} / \mathrm{day}$ ) relapsed at 12 months compared to $64 \%$ (35/55) of paediatric placebo patients (RR $0.97,95 \% \mathrm{Cl} 0.72$ to $1.31 ; 102$ patients; moderate-quality evidence). There was no statistically significant difference in the proportion of patients who experienced an adverse event, withdrawal due to adverse events or serious adverse events. Thirty-four per cent (307/900) of 5-ASA patients had at least one adverse event compared to 33\% (301/914) of placebo patients (RR $1.05,95 \% \mathrm{Cl} 0.95$ to $1.17 ; 10$ studies; 1814 patients). Fourteen per cent (127/917) of 5-ASA patients withdrew due to adverse events compared to $13 \%$ (119/916) of placebo patients (RR 1.11, 95\% Cl 0.88 to $1.38 ; 9$ studies; 1833 patients). One per cent (3/293) of 5-ASA patients had a serious adverse event compared to $0.7 \%$ (2/283) of placebo patients (RR $1.43,95 \% \mathrm{Cl} 0.24$ to $2.83 ; 3$ studies; 576 patients). Common adverse events reported in the studies included diarrhoea, nausea and vomiting, abdominal pain, headache and skin rash.

\section{Authors' conclusions}

We found no evidence in this review to suggest that oral 5-ASA preparations are superior to placebo for the maintenance of medicallyinduced remission in patients with Crohn's disease. Additional randomised trials may not be justified.

\section{PLAIN LANGUAGE SUMMARY}

\section{Oral 5-aminosalicylic acid drugs for maintenance of medically-induced remission in Crohn's disease}

\section{What is Crohn's disease?}

Crohn's disease is a chronic inflammatory disorder that can involve any part of the gastrointestinal tract. It can affect people of any age. When people have active Crohn's disease they experience symptoms such as abdominal pain, diarrhoea and weight loss. When symptoms stop, people are considered to be in remission. Active Crohn's disease can be treated by medical therapy (e.g. drugs such as steroids, immunosuppressives or biologics) or by surgery to removed the diseased portions of the intestine. The goal of medical therapy of Crohn's disease is to induce remission and to maintain this remission for as long as possible.

\section{What are 5-aminosalicylic acid (5-ASA) drugs?}

5-ASA drugs are a group of compounds that are thought to treat Crohn's disease by reducing inflammation in the gastrointestinal tract. These drugs are often taken orally (i.e. by mouth).

\section{What did the researchers investigate?}

We studied whether oral 5-ASA maintains remission in patients with Crohn's disease and whether it causes any harms (side effects). We searched the medical literature extensively up to 8 June 2016.

\section{What did the researchers find?}

We found 12 studies that included a total of 2146 participants. Eleven studies including 2014 adult participants compared oral 5-ASA to a placebo (i.e. inactive pills or tablets). One study including 132 children compared oral 5-ASA to a placebo. Eleven studies were conducted for 12 months and one study was conducted for 24 months. Seven studies were judged to be of high quality and the other studies were judged to be of unclear quality because insufficient details were reported to allow for a judgement about quality. The studies with insufficient details were generally older studies that were published 20 or more years ago. A combined analysis of eleven studies including 2014 adult participants found no difference between oral 5-ASA (at daily doses between $1.6 \mathrm{~g}$ to $4 \mathrm{~g}$ ) and placebo in the proportion of participants who remained in remission at 12 months. Similarly, a study including 161 adult participants found no difference between oral 5-ASA (at a dose of $2 \mathrm{~g}$ per day) and placebo in the proportion of participants who remained in remission at 24 months. The study involving children found no difference between oral 5-ASA (at a daily dose of $50 \mathrm{mg} / \mathrm{kg}$ ) and placebo in the proportion of participants who remained in remission at 12 months. There does not appear to be an increased risk of side effects in people who take oral 5-ASA compared to placebo. Common adverse events reported in the studies included diarrhoea, nausea and vomiting, abdominal pain, headache and skin rash.

In conclusion, there is no evidence that oral 5-ASA is superior to placebo for helping people with Crohn's disease remain in remission that was achieved by medical therapy. 
SUMMARY OF FINDINGS

Summary of findings for the main comparison. 5-ASA compared to placebo for maintenance of medically-induced remission in Crohn's disease

5-ASA compared to placebo for maintenance of medically-induced remission in Crohn's disease

Patient or population: patients with maintenance of medically-induced remission in Crohn's disease Settings:

Intervention: 5-ASA compared to placebo

\begin{tabular}{|c|c|c|c|c|c|c|}
\hline \multirow[t]{3}{*}{ Outcomes } & \multicolumn{2}{|c|}{ Illustrative comparative risks* $(95 \% \mathrm{Cl})$} & \multirow{3}{*}{$\begin{array}{l}\text { Relative effect } \\
(95 \% \mathrm{CI})\end{array}$} & \multirow{3}{*}{$\begin{array}{l}\text { No of Partici- } \\
\text { pants } \\
\text { (studies) }\end{array}$} & \multirow{3}{*}{$\begin{array}{l}\text { Quality of the } \\
\text { evidence } \\
\text { (GRADE) }\end{array}$} & \multirow[t]{3}{*}{ Comments } \\
\hline & Assumed risk & Corresponding risk & & & & \\
\hline & Control & $\begin{array}{l}\text { 5-ASA compared to } \\
\text { placebo }\end{array}$ & & & & \\
\hline $\begin{array}{l}\text { Relapse, drop-outs classed as relapse, } \\
\text { grouped by length of follow-up - } 12 \\
\text { months }\end{array}$ & 535 per $1000^{1}$ & $\begin{array}{l}525 \text { per } 1000 \\
\text { (487 to } 573)\end{array}$ & $\begin{array}{l}\text { RR } 0.98 \\
\text { (0.91 to } 1.07)\end{array}$ & $\begin{array}{l}2014 \\
\text { (11 studies) }\end{array}$ & $\begin{array}{l}\oplus \oplus \oplus \ominus \\
\text { moderate } 2\end{array}$ & \\
\hline $\begin{array}{l}\text { Relapse, drop-outs classed as relapse, } \\
\text { grouped by length of follow-up - } 24 \\
\text { months }\end{array}$ & 679 per $1000^{3}$ & $\begin{array}{l}\mathbf{6 7 2} \text { per } 1000 \\
(543 \text { to } 835)\end{array}$ & $\begin{array}{l}\text { RR } 0.99 \\
(0.8 \text { to } 1.23)\end{array}$ & $\begin{array}{l}161 \\
\text { (1 study) }\end{array}$ & $\begin{array}{l}\oplus \oplus \ominus \ominus \\
\text { low } 4,5\end{array}$ & \\
\hline $\begin{array}{l}\text { Relapse, drop-outs classed as relapse, } \\
\text { grouped by length of follow-up - Pedi- } \\
\text { atric }\end{array}$ & 688 per $1000^{3}$ & $\begin{array}{l}736 \text { per } 1000 \\
\text { (591 to } 914)\end{array}$ & $\begin{array}{l}\text { RR } 1.07 \\
\text { (0.86 to } 1.33)\end{array}$ & $\begin{array}{l}132 \\
\text { (1 study) }\end{array}$ & $\begin{array}{l}\oplus \oplus \oplus \ominus \\
\text { moderate } 6\end{array}$ & \\
\hline Withdrawals due to adverse events & 130 per $1000^{1}$ & $\begin{array}{l}\mathbf{1 4 4} \text { per } \mathbf{1 0 0 0} \\
\text { (114 to } 179)\end{array}$ & $\begin{array}{l}\text { RR } 1.11 \\
\text { (0.88 to } 1.38)\end{array}$ & $\begin{array}{l}1833 \\
\text { (10 studies) }\end{array}$ & $\begin{array}{l}\oplus \oplus \ominus \ominus \\
\text { low } 8,9\end{array}$ & \\
\hline Serious adverse events & 7 per $1000^{1}$ & $\begin{array}{l}10 \text { per } 1000 \\
(2 \text { to } 60)\end{array}$ & $\begin{array}{l}\text { RR } 1.43 \\
\text { (0.24 to } 8.44)\end{array}$ & $\begin{array}{l}576 \\
\text { (3 studies) }\end{array}$ & $\begin{array}{l}\oplus \oplus \oplus \ominus \\
\text { low } 10\end{array}$ & \\
\hline
\end{tabular}

${ }^{\star}$ The basis for the assumed risk (e.g. the median control group risk across studies) is provided in footnotes. The corresponding risk (and its $95 \%$ confidence interval) is based on the assumed risk in the comparison group and the relative effect of the intervention (and its $95 \% \mathrm{Cl}$ ).

Cl: Confidence interval; RR: Risk ratio;

GRADE Working Group grades of evidence

High quality: Further research is very unlikely to change our confidence in the estimate of effect. 
Moderate quality: Further research is likely to have an important impact on our confidence in the estimate of effect and may change the estimate.

Low quality: Further research is very likely to have an important impact on our confidence in the estimate of effect and is likely to change the estimate.

Very low quality: We are very uncertain about the estimate.

1 Control group risk comes from control arm of meta-analysis, based on included trials.

2 Downgraded one level due to unknown risk of bias.

3 Control group risk comes from control arm of the included study.

4 Downgraded one level due to unknown risk of bias.

5 Downgraded one level due to sparse data (109 events).

6 Downgraded one level due to sparse data (94 events).

7 Downgraded one level due to unknown risk of bias.

8 Downgraded one level due to unexplained heterogeneity $(12=55 \%)$

9 Downgraded one level due to sparse data (246 events).

10 Downgraded two levels due to very sparse data (5 events). 


\section{B A C K G R O U N D}

Crohn's disease is a chronic inflammatory disorder that can involve any part of the gastrointestinal tract. Common symptoms include abdominal pain, diarrhoea and weight loss. Crohn's disease is characterized by chronicity and recurrences. There is no cure for Crohn's disease.Thus, treatment is directed towards inducing and maintaining remission, and addressing complications.

The prevention of relapse is a major issue in the management of Crohn's disease. Corticosteroids, the main treatment for acute exacerbations, are not effective for maintenance of remission in Crohn's disease (Steinhart 2003), and long-term use of corticosteroids is limited by numerous adverse events.

5 -aminosalicylates are a group of compounds that have long been used in inflammatory bowel disease. The first 5-aminosalicylate agent used in clinical practice was sulphasalazine, which is composed of sulphapyridine linked by an azo bond to 5aminosalicylic acid (5-ASA). Sulphasalazine was first used in the 1940 s as a treatment for arthritis (Svartz 1942). Improvement in gastrointestinal symptoms was noted in patients who had concurrent ulcerative colitis leading to further use of this agent in inflammatory bowel disease.

The majority of an oral dose of sulphasalazine reaches the colon where the azo-bond is split by an azo reductase released by colonic bacteria, yielding 5-ASA and sulphapyridine. Virtually all the sulphapyridine is absorbed from the colon whereas most of 5ASA remains within the colon and is excreted in the stool. Several studies have shown that 5-ASA is the active therapeutic moiety of sulphasalazine and that sulphapyridine acts only as a carrier molecule to deliver 5-ASA to the colon (Azad Khan 1977; Klotz 1980; van Hees 1980). Yet it is the sulphapyridine which is responsible for most of the severe adverse effects of sulphasalazine (Schroder 1972). Sulphapyridine undergoes acetylation in the liver with subsequent excretion in the urine. Slow acetylators show more of the adverse effects of this component secondary to accumulation of sulphapyridine in the blood prior to excretion in the kidneys (Das 1973).

Recognition that 5-ASA is the active ingredient of sulphasalazine and that sulphapyridine is responsible for most of the side effects led to several investigations of the use of 5-ASA as a single agent for the treatment of inflammatory bowel disease. 5-ASA in an unprotected form is, however, readily absorbed in the proximal small intestine (Myers 1987), and does not reach the distal bowel in therapeutic concentrations. There have been several formulations of 5-ASA designed to inhibit proximal absorption and to ensure delivery to distal sites of inflammation. There are two basic ways in which 5-ASA can be protected: by linking it to itself or to another carrier and by the use of slow release preparations of 5ASA. Different 5-ASA preparations may allow delivery of 5-ASA to different locations in the gastrointestinal tract.

5-ASA formulations include azo compounds, mesalazine delayedrelease agents and mesalazine slow-release formulations. For azo compounds a carrier molecule is linked to 5-ASA by an azo bond using the same principle as sulphasalazine. Olsalazine consists of two molecules of 5-ASA joined together whilst balsalazide is a prodrug in which a 5-ASA molecule is linked to 4-aminobenzoyl-Balanine, an inert and biologically inactive carrier molecule. Like sulphasalazine, the azo bond of these drugs is split in the colon by bacterial azo-reductases, releasing 5-ASA to exert local therapeutic activity. Mesalazine delayed-release agents (Eudragit-coated) are coated with a resin designed to dissolve at a certain $\mathrm{pH}$. Asacol is coated with Eudragit $\mathrm{S}$ which dissolves above $\mathrm{pH} 7.0$ to release 5ASA in the terminal ileum and colon. Eudragit-L coated mesalazine (Salofalk) dissolves above pH 6.0 to release 5-ASA in the terminal ileum and colon. Mesalazine slow-release formulations include drugs such as Pentasa. Pentasa contains microgranules of 5-ASA that are individually coated with ethylcellulose. The microgranules are dispersed in the gut providing a slow, steady release of 5-ASA along the length of the intestine from the upper small bowel to the colon.

These 5-ASA preparations were intended to avoid the adverse side effects of sulphasalazine whilst maintaining its therapeutic benefits. Several randomised controlled trials have been published, comparing various 5-ASA agents to placebo, with conflicting results (De Franchis 1997; Gendre 1993; Mahmud 2001; Sutherland 1997). Three previous meta-analyses have suggested that 5-ASA may be beneficial for the maintenance of remission in Crohn's disease (Camma 1997; Messori 1994; Steinhart 1994), but in one report the only bibliographic database searched was MEDLINE (Camma 1997), and another did not report how the quality of included studies was assessed (Messori 1994). Furthermore, a number of recent randomised controlled trials have been published since these meta-analyses were reported. An up to date systematic review using the Cochrane Collaboration format is indicated to summarise the current evidence on the use of 5-ASA agents for the maintenance of medically-induced remission in Crohn's disease. When possible, data on outcomes were pooled together for metaanalyses. This systematic review is an update of a previously published Cochrane review (Akobeng 2005). The use of 5-ASA agents for the prevention of recurrences following surgery for Crohn's disease was not the subject of this review and is covered by a separate systematic review (Gordon 2011).

\section{O B JECTIVES}

1. To evaluate the efficacy of 5-ASA agents for the maintenance of medically-induced remission in Crohn's disease.

2. To determine adverse events associated with 5-ASA treatment in Crohn's disease.

\section{METHODS}

\section{Criteria for considering studies for this review Types of studies}

Randomised controlled trials were considered for inclusion.

\section{Types of participants}

Patients of any age with Crohn's disease in remission as defined by a recognized Crohn's disease activity index or endoscopy were considered for inclusion.

\section{Types of interventions}

Trials that compared oral 5-ASA agents to placebo or sulphasalazine with a treatment duration of at least six months were considered for inclusion. 


\section{Types of outcome measures}

The primary outcome measure was the occurrence of clinical or endoscopic relapse as defined by the primary studies. Secondary endpoints included time to relapse, adverse events, withdrawals due to adverse events and serious adverse events.

\section{Search methods for identification of studies}

\section{A. Electronic searching}

We searched the following electronic databases from inception to 8 June 2016 for relevant studies:
1. MEDLINE;
2. EMBASE;
3. CENTRAL; and
4. Cochrane IBD Group Specialized Register.

The search strategy was not limited by language (see Appendix 1).

\section{B. Reference searching}

The references of all identified studies were inspected for more trials.

\section{Abstracts of major gastroenterology meetings}

A manual search of abstracts submitted to major gastroenterology meetings (1995 to 2016) was performed in the following journals to identify more trials:

1. Gastroenterology (American Gastroenterological Association);

2. Gut (British Society of Gastroenterology);

3. American Journal of Gastroenterology (American College of Gastroenterology);

4. Canadian Journal of Gastroenterology (Canadian Association of Gastroenterology);

5. Journal of Pediatric Gastroenterology and Nutrition (European Society of Paediatric Gastroenterology, Hepatology and Nutrition); and

6. Journal of Pediatric Gastroenterology and Nutrition (North American Society of Paediatric Gastroenterology, Hepatology and Nutrition).

\section{Personal contacts}

Leaders in the field were contacted to try to identify other studies.

\section{E. Drug companies}

The manufacturers of 5-ASA agents were contacted for additional data.

\section{Data collection and analysis}

Papers (or abstracts) that appeared to be potentially relevant were identified by two authors (DZ and JKM). The authors (DZ and JKM), after reading the full texts, independently assessed the eligibility of all trials identified using the inclusion criteria above. Disagreement among authors was discussed and agreement reached by consensus.

\section{Quality assessment}

The methodological quality of the included studies was independently evaluated by two authors (DZ and JKM) using the Cochrane risk of bias tool (Higgins 2011). Each trial was rated as high, low, or unclear risk of bias for each of the following criteria:

1. Randomisation sequence generation;

2. Allocation concealment;
3. Blinding;

4. Incomplete outcome data;

5. Selective reporting; and

6. Other sources of bias.

The overall quality of the evidence supporting the primary outcomes was evaluated using the GRADE approach (Guyatt 2008; Schünemann 2011). Randomised trials are considered to provide high quality evidence, but may be downgraded due to: (1) risk of bias, (2) indirectness of evidence, (3) inconsistency (unexplained heterogeneity), (4) imprecision (sparse data), and (5) reporting bias (publication bias). The different quality ratings are interpreted as the likelihood that future research would change the effect estimate. Further research is unlikely to change the effect estimate if the evidence is high quality. If the overall evidence is of moderate quality further research may have an impact on our confidence in the effect estimate and may change the estimate. Further research is very likely to have an important impact on our confidence in the estimate of effect and is likely to change the estimate when the evidence is rated as low quality. Very low quality research means that we are very uncertain about the finding (Guyatt 2008; Schünemann 2011).

\section{DATA COLLECTION}

A data extraction form was developed and used to extract information on relevant features and results of included studies. Two authors (DZ and JKM) independently extracted and recorded data on the predefined checklist. Extracted data included the following items:

a. characteristics of patients: age, sex, disease distribution, disease duration, disease activity index;

b. total number of patients originally assigned to each treatment group;

c. intervention: type and dose of 5-aminosalicylate;

d. control: placebo, other drugs;

e. concurrent medications; and

f. outcomes: time of assessment, length of follow up, type of Crohn's disease activity index used, definitions of remission and relapse, relapse rates, adverse events.

\section{STATISTICAL ANALYSIS}

The Cochrane Collaboration review manager (RevMan) software (version 5.3.5) was used for data analysis. Patients with final missing outcomes were assumed to have relapsed. Analyses were grouped by length of follow-up.

Dichotomous variables

We calculated the risk ratio (RR) and corresponding 95\% confidence interval $(\mathrm{Cl})$ for dichotomous outcomes. We pooled studies for meta-analysis when patients, outcomes, and interventions were deemed to be sufficiently similar (determined by consensus). A fixed-effect model was used to pool data.

\section{Heterogeneity}

Heterogeneity among trial results was assessed by visual inspection of forest plots and by calculating the $\mathrm{Chi}^{2}$ and $\mathrm{I}^{2}$ statistics. We aimed to further investigate potential sources of heterogeneity.

Publication Bias 
The possibility of a publication bias was investigated through the construction of funnel plots (trial effects versus trial size).

\section{Sensitivity analyses}

Sensitivity analyses were conducted based on the following:

a. only including patients whose outcome is known (i.e. an available case analysis where the number of patients who completed the study are used as the denominator); and

b. random-effects versus fixed-effect models.

We also planned to consider the effect of:

c. allocation concealment;

d. type of 5 ASA;

e. dose of 5 ASA; and

f. concurrent medications (especially immunosuppressants such as azathioprine, 6-mercaptopurine, methotrexate, cyclosporine and mycophenolate mofetil).

\section{RES U L T S}

\section{Description of studies}

A literature search conducted on 8 June 2016 identified 10,137 studies. Five additional studies were identified through searching of references. After duplicates were removed a total of 7023 reports remained for review of titles and abstracts. Two authors independently reviewed titles and abstracts and 37 potentially relevant reports on the use of 5-ASA agents for the maintenance of medically-induced remission in Crohn's disease were selected for full text review (See Figure 1). Twenty reports of 15 studies were excluded (See Characteristics of excluded studies). Five studies were excluded because allocation of patients to treatment was not random (Bresci 1991; Bresci 1994; Hanauer 1993; Lichtenstein 2009; Nakshabendi 1992). One study was excluded because the duration of treatment was four months (Brignola 1992). Camma 1997 was excluded because it was a systematic review and Luthra 2002 was excluded because it was a commentary on a published trial. Five studies were excluded because they compared sulphasalazine to placebo (Ewe 1976; Lennard-Jones 1977; Malchow 1981; Malchow 1984; Summers 1979). Schreiber 1994 was excluded because it compared 5-ASA to 4-ASA. Anthonisen 1974 was excluded the participants had active Crohn's disease and were not in remission. 
Figure 1. Study flow diagram.

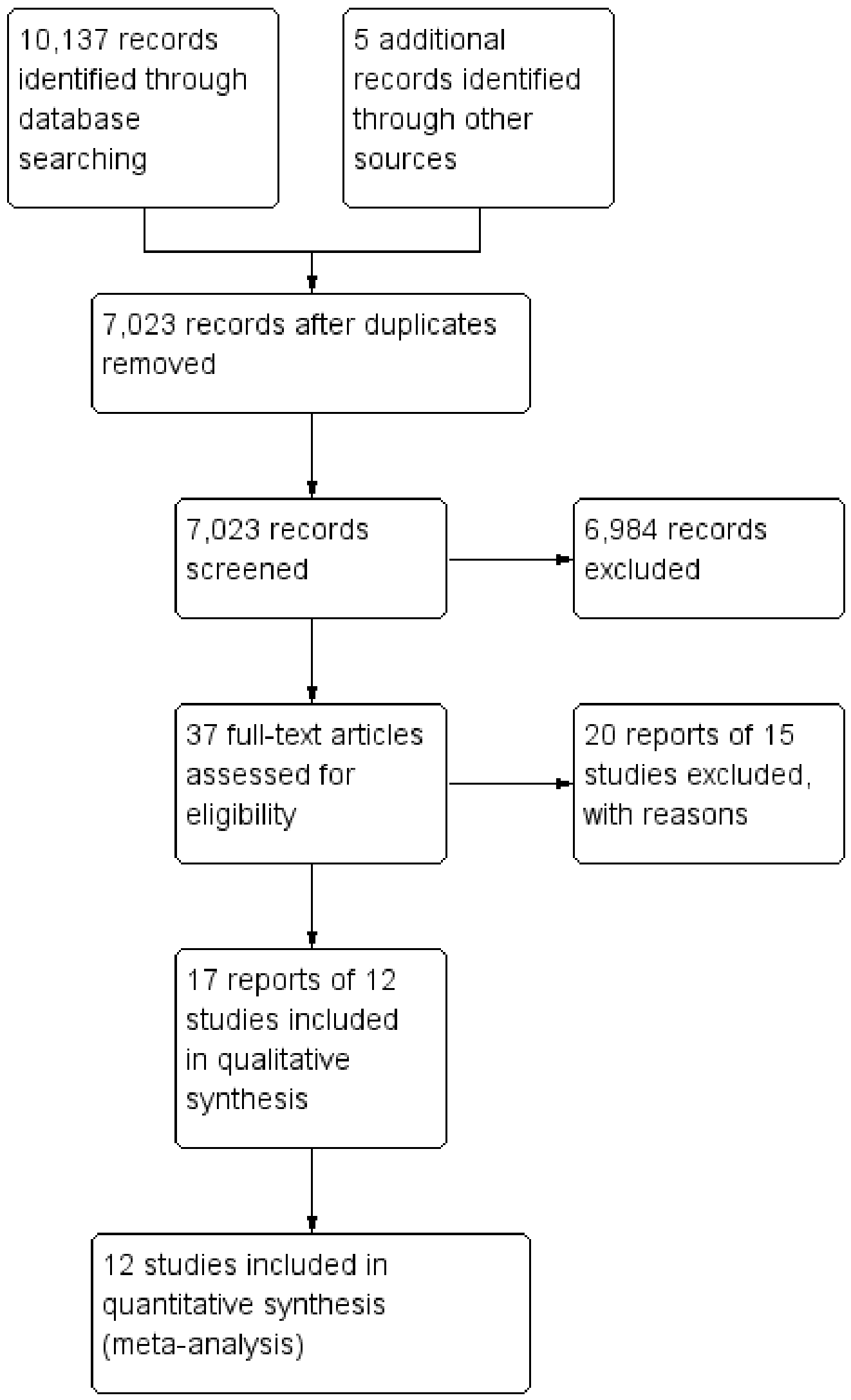


Eighteen reports of 12 studies involving a total of 2146 patients, were selected for inclusion (Anonymous 1990; Arber 1995; Bondesen 1991; Cezard 2009; De Franchis 1997; Gendre 1993; Mahmud 2001; Modigliani 1996; Prantera 1992; Sutherland 1997; Thomson 1995; Wellman 1988). All twelve included studies were randomised controlled trials that compared oral 5-ASA agents to placebo for the maintenance of medically-induced remission in Crohn's disease (see Characteristics of included studies). None of the included studies compared 5-ASA to sulphasalazine. The participants of eleven of the included studies were adults (aged $>18$ ). Cezard 2009 enrolled paediatric participants (aged $<18$ years). In 10 of the studies, the duration of follow-up was 12 months (Anonymous 1990; Arber 1995; Cezard 2009; De Franchis 1997; Mahmud 2001; Modigliani 1996; Prantera 1992; Sutherland 1997; Thomson 1995; Wellman 1988). Gendre 1993 followed up patients at 12 and 24 months. Bondesen 1991 followed up patients at 6 month intervals for 12 to 18 months. In 11 of the included studies, the diagnosis of Crohn's disease was established by conventional clinical, radiologic, endoscopic or histologic criteria. Bondesen 1991 did not describe how the diagnosis Crohn's disease was established. In two studies (Arber 1995; Cezard 2009), the Harvey Bradshaw activity index (Softley-Clamp modification) was used to measure relapse whilst the other studies used the Crohn's Disease Activity Index (CDAI).

\section{Studies with 12 months follow-up}

Anonymous 1990

Sample

Two hundred and forty-eight patients were randomised from eight centres in Europe, Canada and South Africa. Patients had to be in remission at time of entry $(C D A I<150)$ and their disease had to be been controlled (i.e. no steroids or stable low dose prednisone $2.5 \mathrm{mg} /$ day or less) for the preceding month prior to entry. Exclusion criteria included ileostomy or colostomy, obstruction, perforation or haemorrhage, total parental nutrition, treatment with metronidazole, azathioprine or disodium cromoglycate, known sensitivity to salicylates, other significant disease or unsuitability to participate in the trial. Patients subsequently found not to meet the inclusion criteria after randomisation were excluded from the analysis. The age of the 206 patients ( 115 males, 91 females) who were included in the per protocol analysis ranged from 16 to 75 years.

Treatment

Patients were randomised to receive either 5-ASA (Mesasal/ Claversal) $1.5 \mathrm{~g} /$ day or placebo. Only anti-diarrhoeal agents were allowed as additional medications.

Endpoints

Patients were followed up for 12 months and were considered to have relapsed if the CDAl became $>150$ and had increased 60 points from baseline. Secondary outcomes included adverse events and withdrawal due to adverse events.

\section{Arber 1995}

Sample

Fifty-nine patients (37 men, 22 women) were recruited from 9 gastroenterology centres in Israel. All patients had proven Crohn's disease of at least one years duration and were in continuous remission for at least six months (Harvey-Bradshaw index $<4$ ), while being treated with only 5-ASA, sulphasalazine or no therapy. Other exclusion criteria were not reported.

Treatment
Participants were randomised to receive either mesalazine (Rafasal) $250 \mathrm{mg}$ tablets $(2 \times 2$ per day) $(n=28)$ or placebo $(n=31)$. Restrictions on concomitant medications were not reported.

Endpoints

Patients were followed up for 12 months and primary trial endpoints were 1-year follow-up, or clinical relapse (rise of more than four points on the Harvey Bradshaw index). Secondary outcomes included adverse events and withdrawal due to adverse events.

\section{Bondesen 1991}

Sample

Two hundred and two patients were recruited from eight gastroenterology centres in Denmark. Patients had to have clinically inactive Crohn's disease. There were no differences between the treatment groups with respect to sex, age, disease duration or location, prior medical or surgical treatment, length of remission, CDAl at entry or adherence with medication regimen.

\section{Treatment}

Patients were randomised to receive either 5-ASA (Pentasa) $1.5 \mathrm{~g}$ twice a day $(n=101)$ or placebo $(n=101)$.

\section{Endpoints}

Patients were follow up at 6 month intervals for 12 to 18 months and trial endpoints were relapse and adverse events.

\section{Cezard 2009}

Sample

One hundred and thirty-two paediatric patients (age $<18$ years) were recruited from 17 centres (16 from France and 1 from Switzerland). Patients had to be diagnosed with Crohn's disease before the age of 16 and were in clinical remission within six months of flare-up treatment. Exclusion criteria included previous treatment with mesalazine or immunosuppressants or known hypersensitivity to salicylates.

\section{Treatment}

Patients were randomised to receive either 5-ASA $50 \mathrm{mg} / \mathrm{kg} /$ day (n $=68)$ or placebo $(n=64)$.

\section{Endpoints}

Patients were followed up for 12 months and trial endpoints included relapse, adverse events, withdrawal due to adverse events and serious adverse events.

\section{Mahmud 2001}

Sample

Three hundred and twenty-seven patients ( 150 males, 177 females; age $>18$ years) were recruited from 3 European countries (Ireland, United Kingdom and France). Patients were diagnosed with Crohn's disease within five years of entry, and had to be in remission for at least one month prior to randomisation (CDAl < 150). Steroids, azathioprine or other immunosuppressive therapy was not allowed within one month of the pre-study visit nor was concomitant therapy with antibiotics for more than one month. Other exclusion criteria included pregnancy, intending to be pregnant or breast feeding, clinically significant hepatic or renal insufficiency, strictures causing mechanical obstruction, fistulae, oral or symptomatic anal Crohn's disease, stoma or significant small bowel disease apart from terminal ileal disease and patients with known hypersensitivity to salicylates. 


\section{Treatment}

Participants were randomised to receive either $2 \mathrm{~g} /$ day of 5-ASA (Olsalazine) or placebo. No other active medication for Crohn's disease was allowed, but antidiarrhoeal agents were permitted. Endpoints

Patients were followed up for a total of 12 months. The primary endpoint of efficacy was relapse defined as a CDAI > 150 or an increase in the CDAI score by 60 points or more from the baseline at visit 2 (week 0 ), or the need for additional therapy or surgery.

Prantera 1992

Sample

One hundred and twenty-five patients (78 males, 47 females; age range 23 to 48 years) were recruited from 8 Italian centres. All patients were in remission (defined as a CDAl < 150) for at least 3 months, but not more than 2 years and had not taken corticosteroids, sulphasalazine or metronidazole for at least 3 months or azathioprine for at least 6 months prior to entry. Other exclusion criteria included intestinal strictures 12 months prior to entry; Crohn's disease close to the ileum; active perianal or extraintestinal Crohn's disease; internal and external fistulas; sensitivity to aminosalicylates; and "other usual criteria for excluding participation in a clinical trial".

Treatment

Participants were randomised to receive either 5-ASA (Asacol) 2.4 $\mathrm{g} /$ day $(\mathrm{n}=64)$ or placebo $(\mathrm{n}=61)$. Restrictions on concomitant medications were not reported.

Endpoints

Patients were followed up for 12 months. The primary study endpoint was clinical relapse defined as CDAI > 150 with an increase of 100 points over the baseline. Secondary outcomes included adverse events and withdrawal due to adverse events.

\section{Sutherland 1997}

Sample

Two hundred and ninety-three patients ( aged $\geq 18$ years old) were recruited from 31 Canadian centres. Patients had to be in remission (CDAl $<150$ and no symptoms for 30 days prior to entry) and have reported at least two flares within the last four years, with one flare or a recent resection within 18 months. Participants should not have taken immunosuppressives within 90 days, corticosteroids within 30 days or mesalamine or metronidazole within 7 days of entry. Other exclusion criteria included total proctocolectomy, short-bowel syndrome, three or more resections within the last 10 years, chronic perianal disease, ulcerative colitis, positive stool tests for pathogens, parasites or Clostridium difficile toxin, drug or alcohol abuse, hepatic, neurological, endocrine, renal or other major systemic disease, and cancer (excluding basal or squamous cell skin), inability to provide informed consent, and sensitivity to salicylates.

Treatment

Patients were randomised to receive either 5-ASA (capsules of microsphere coated with ethylcellulose) $3 \mathrm{~g} /$ day or placebo. Other active medications for Crohn's disease were not allowed but codeine and loperamide were permitted for the control of diarrhoea.

Endpoints

Patients were followed up for 12 months. The primary outcome measure was relapse defined as CDAI $>150$ or an increase of at least 60 points from baseline. Secondary outcomes included adverse events, withdrawal due to adverse events and serious adverse events.
Thomson 1995

Sample

Two hundred and seven participants (101 females, 106 males; age range 18 to 71 years) were recruited from 7 European countries, Canada, South Africa and Israel. Patients had to be in remission (CDAl < 150), and have had one flare within 18 months of study entry. Azathioprine, other immunosuppressives or corticosteroids were not permitted within one month of entry. Other exclusion criteria included pregnancy and previous gastrointestinal surgery with more than $100 \mathrm{~cm}$ of bowel excised.

Treatment

Patients were randomised to receive either $3 \mathrm{~g} /$ day of 5 ASA (Claversal/Mesasal) or placebo. Other active medications for Crohn's disease were not allowed with the exception of antidiarrhoea drugs. Short-term antibiotics were allowed for nonintestinal infections.

Endpoints

Patients were followed up for 12 months. The primary outcome measure was relapse defined as a CDAl score greater than 150 with at least a 60-point increase from the baseline index score. Secondary outcomes included adverse events and withdrawal due to adverse events.

\section{Study with 24 months follow-up}

\section{Gendre 1993}

Sample

One hundred and sixty-one patients ( 77 men, 84 women; age range 17 to 50 years) were recruited from 16 centres in France. All patients had been in remission $(C D A l<150)$ for less than 24 months prior to entry. Steroids or immunosuppressive therapy were not permitted for at least one month before entry. Other exclusion criteria included curative surgery, perianal disease or planned pregnancy.

Treatment

Patients were randomised to receive either mesalazine (Pentasa), $2 \mathrm{~g} /$ day $(\mathrm{n}=80)$ or placebo $(\mathrm{n}=81)$. Antispasmodics, antidiarrhoeal drugs, cholestyramine and sedatives were allowed.

Endpoints

Patients were followed up for 24 months and trial endpoints included surgery for acute complications, clinical relapse (defined as CDAI of $>250$ or a CDAl between 150 and 250 with an increase of $>50$ points from baseline), adverse events, and withdrawal due to adverse events.

\section{Risk of bias in included studies}

The results of the risk of bias analysis are summarized in Figure 2. Random sequence generation was rated as low risk of bias in seven studies (Anonymous 1990; Arber 1995; Cezard 2009; Mahmud 2001; Prantera 1992; Sutherland 1997; Thomson 1995) and as unclear risk of bias in five studies (Bondesen 1991; De Franchis 1997; Gendre 1993; Modigliani 1996; Wellman 1988). Allocation concealment was rated as low risk of bias in seven studies (Anonymous 1990; Arber 1995; Cezard 2009; De Franchis 1997; Prantera 1992; Sutherland 1997; Thomson 1995) and as unclear risk of bias in five studies (Bondesen 1991; Gendre 1993; Mahmud 2001; Modigliani 1996; Wellman 1988). Blinding of participants and personnel was judged to be adequate in 10 studies and unclear risk of bias in two studies (Bondesen 1991; Wellman 1988). The blinding of outcome assessors was judged to be adequate in nine studies and unclear risk of bias in three studies (Bondesen 1991; De Franchis 1997; Wellman 1988). Bondesen 1991 did not describe drop-outs and 
was rated as unclear risk of bias for incomplete outcome data. Mahmud 2001 was rated as unclear risk of bias for incomplete outcome data because more patients in the olsalazine group failed to complete the study compared to placebo patients. Reasons for patients withdrawal were given in all studies, though no study reported post-withdrawal data for any patient. The percentage of randomised patients with unknown outcome at the end of study ranged from 3\% (Wellman 1988) to 34\% (Modigliani 1996; Thomson 1995). For most studies more patients in the 5-ASA arm had unknown outcomes compared to the placebo arm, this difference ranged from $3 \%$ (Sutherland 1997) to $16 \%$ (Mahmud 2001). See additional Table 1 for more information. Five studies were judged to be at low risk of bias for selective reporting (Cezard 2009; Mahmud 2001; Modigliani 1996; Thomson 1995; Wellman 1988). Six studies were judged to be at unclear risk of bias for selective reporting for reporting on some post hoc subgroup analyses (Anonymous 1990; Arber 1995 ; De Franchis 1997; Gendre 1993; Prantera 1992; Sutherland 1997). However, these subgroup analyses would generally be expected for this type of study. Bondesen 1991 was judged to be at unclear risk of bias for selective reporting and other bias because it was an abstract publication that provided insufficient details to allow a judgement. The other studies were rated as low risk of bias for other potential sources of bias. 
Figure 2. Risk of bias summary: review authors' judgements about each risk of bias item for each included study.

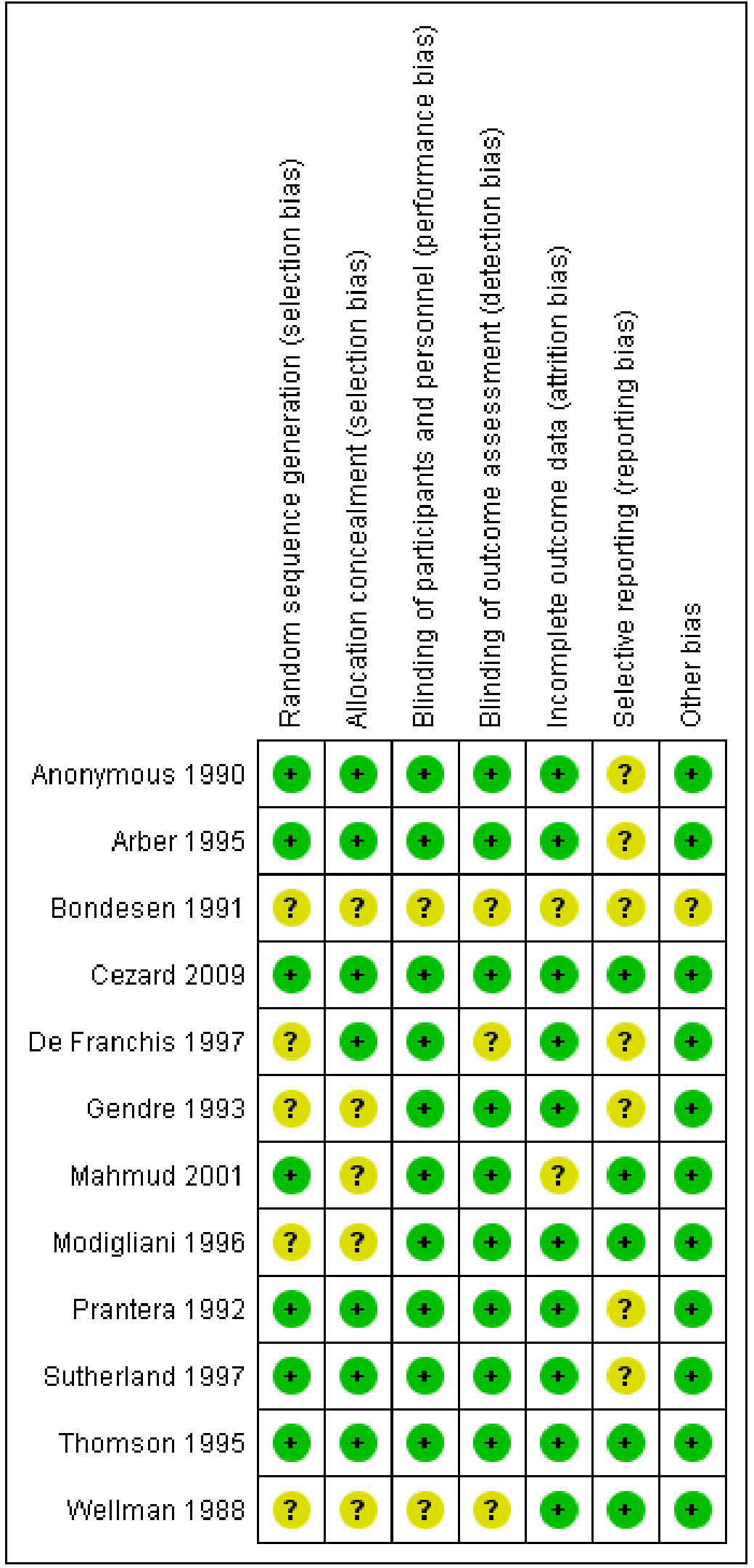




\section{Effects of interventions}

See: Summary of findings for the main comparison 5-ASA compared to placebo for maintenance of medically-induced remission in Crohn's disease

\section{Efficacy}

\section{Occurrence of relapse}

For the main analysis, we used as the denominator the total number of patients randomised. We assumed that participants who dropped out of the study, and on whom there were no post withdrawal information, had relapsed during the study period. There was no statistically significant difference in relapse rates in patients who were followed for 12 months. Fifty-three per cent (526/998) of 5-ASA patients relapsed at 12 months compared to $54 \%$ (544/1016) of placebo patients (RR $0.98,95 \%$ Cl 0.91 to $1.07 ; 11$ studies; 2014 patients; Figure 3). No significant heterogeneity was detected for this comparison $(12=33 \%, P=0.14)$. A GRADE analysis indicated that the overall quality of the evidence supporting this outcome was moderate due to an unknown risk of bias in some studies in the pooled analysis (See Summary of findings for the main comparison). A sensitivity analysis using a random-effects model had little effect on the results (RR $0.98,95 \% \mathrm{Cl} 0.88$ to 1.08 ). There was no statistically significant difference in relapse rates at 24 months. Sixty-eight per cent (54/80) of 5-ASA patients relapsed at 24 months compared to $68 \%$ (55/81) of placebo patients (RR 0.99, 95\% $\mathrm{Cl} 0.80$ to 1.23 , 1 study; 161 patients). A GRADE analysis indicated that the overall quality of the evidence supporting this outcome was low due to an unknown risk of bias (i.e. random sequence generation, allocation concealment and selective reporting) and sparse data (109 events; See Summary of findings for the main comparison). There was no statistically significant difference in relapse rates at 12 months in the paediatric study (Cezard 2009). Seventy-four per cent (50/68) of paediatric 5-ASA patients relapsed at 12 months compared to $69 \%(44 / 64)$ of paediatric placebo patients (RR 1.07, 95\% $\mathrm{Cl} 0.86$ to $1.33 ; 1$ study; 132 patients).

\section{Figure 3. Forest plot of comparison: 1 5-ASA compared to placebo, outcome: 1.1 Relapse, drop-outs classed as} relapse, grouped by length of follow-up.

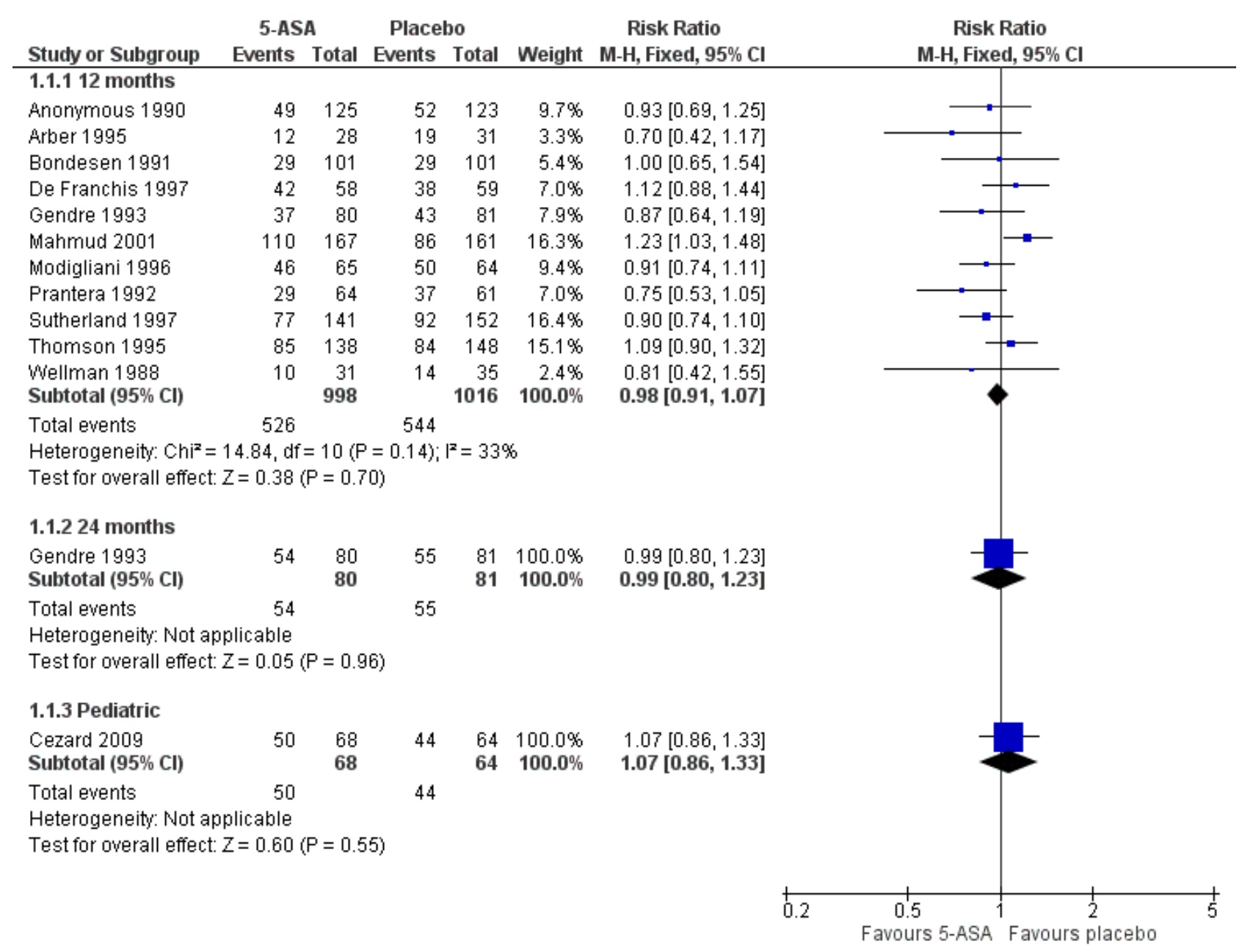

In further sensitivity analyses, we analysed only participants who completed the study and ignored the dropouts (i.e. an available case analysis). There was no statistically significant difference in relapse rates in patients who were followed for 12 months. Thirty- eight per cent (263/689) of 5-ASA patients relapsed at 12 months compared to $42 \%(316 / 749)$ of placebo patients (RR $0.90,95 \% \mathrm{Cl}$ 0.79 to $1.01 ; 11$ studies; 1438 patients). Significant heterogeneity was detected for this comparison $(12=40 \%, P=0.09)$. A sensitivity 
When all dropouts are assumed to have relapsed, there was no significant heterogeneity $(12=33 \% ; P=0.14)$ across the 11 trials that followed up participants for 12 months. However, there was significant heterogeneity in the sensitivity analyses where dropouts were ignored $(12=40 \% ; P=0.09)$. Further investigations of heterogeneity were not felt applicable given the implication of the unknown outcomes on the treatment effect.

\section{Funnel Plots}

A funnel plot analysis for the primary outcome (relapse) provides no convincing evidence of publication bias (see Figure 5).

\section{Figure 5. Funnel plot of comparison: 1 5-ASA compared to placebo, outcome: 1.8 Relapse, drop-outs classed as} relapse, grouped by length of follow-up.

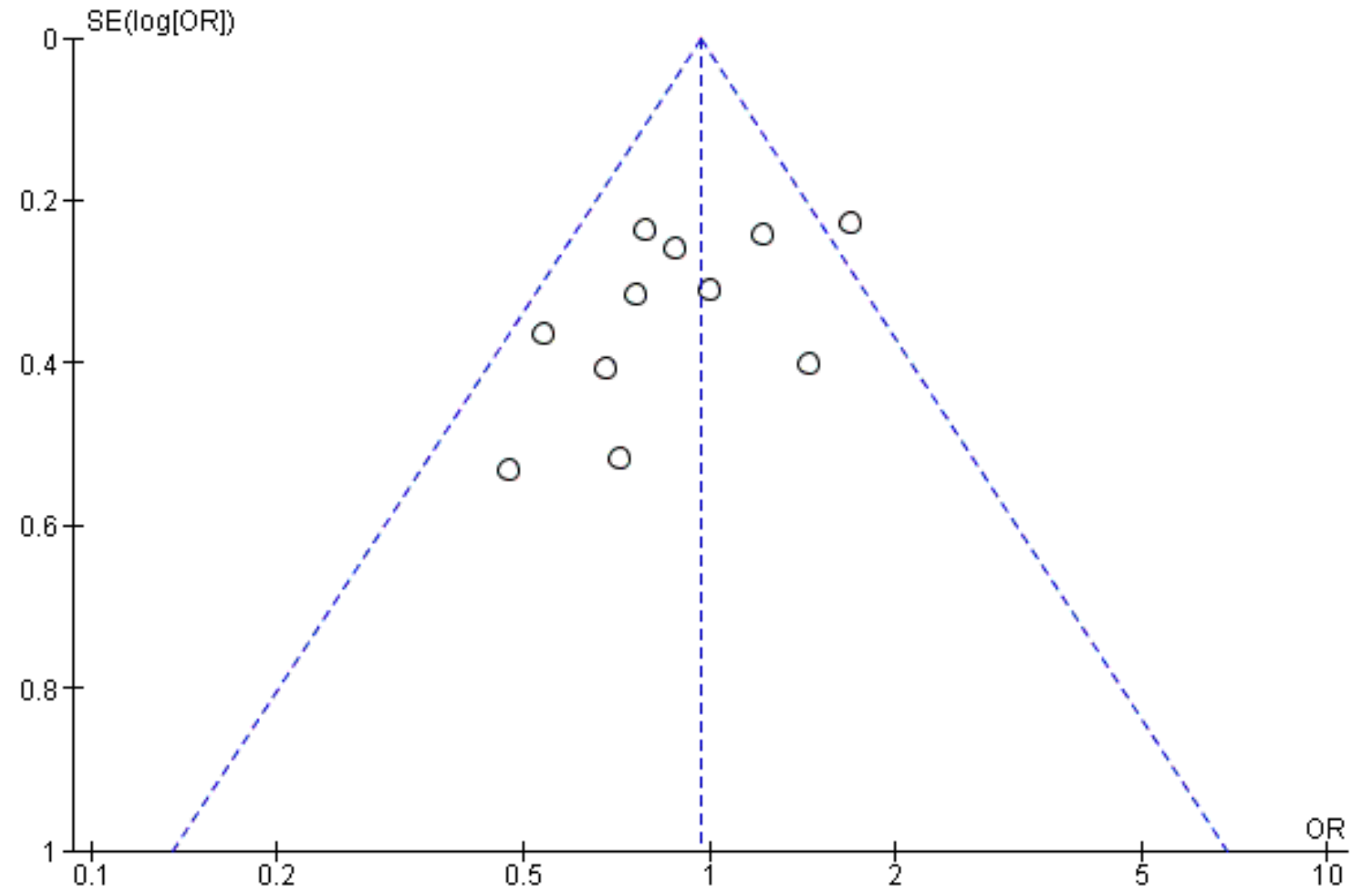

\section{DISCUSSION}

There is no known cure for Crohn's disease, and the disorder is characterised by recurrent flare-ups of symptoms. Lichtenstein 2004 demonstrated in a recent study that being in remission is associated with improved quality of life in patients with Crohn's disease. Preventing relapses should, therefore, be an important goal in the management of this disease.

Whilst a number of treatment regimens are efficacious in inducing clinical remission in active Crohn's disease, no treatment is available that can completely prevent relapse of the disorder (Biancone 2003). Corticosteroids, the mainstay of treatment for active Crohn's disease are not effective as maintenance therapy (Steinhart 2003). Although the antimetabolites, 6-mercaptopurine and its prodrug, azathioprine are effective in maintaining remission in Crohn's disease, these drugs might cause significant adverse events (Feagan 2003). Infliximab, a monoclonal antibody against tumour necrosis factor, is an effective maintenance therapy for patients with Crohn's disease with or without fistulas (Hanauer 2002; Rutgeerts 1999; Sands 2004). Methotrexate is also effective for maintenance of remission in Crohn's disease (Feagan 2000). 5ASA preparations have been found to be superior to placebo for the maintenance of remission in ulcerative colitis (Wang 2016), but its efficacy in Crohn's disease is controversial (Sandborn 2003). Randomised controlled trials which compared 5-ASA agents with placebo for the maintenance of medically-induced remission in Crohn's disease have yielded conflicting results (de Franchis 1997; Gendre 1993; Mahmud 2001; Sutherland 1997). In this review, we have summarised the findings of available randomised controlled trials on the subject.

For the main analyses, we used as the denominator the total number of patients randomised, and assumed that participants who dropped out of the study, and on whom there were no post withdrawal information, had relapsed during the study period. This main analysis demonstrated that, in 11 randomised controlled trials where 2014 participants were followed up for 12 months, there was no statistically significant difference between 5-ASA agents and placebo with regard to the prevention of relapse (RR $0.98,95 \% \mathrm{Cl} 0.91$ to 1.07 ). A GRADE analysis indicates that the overall quality of the evidence supporting this outcome was 
moderate. Sensitivity analyses using a random-effects model and an available case analysis had no impact on the results. A single paediatric study (132 participants) did not find any difference in relapse rates between 5-ASA and placebo treated participants (Cezard 2009). A single study in which patients were followed up for 24 months also did not demonstrate any statistically significant difference in relapse rates between the two groups in either the main analysis or sensitivity analyses. We therefore found no evidence from this study to suggest that 5-ASA agents are superior to placebo for maintenance of medically-induced remission in Crohn's disease.

The primary studies had a number of limitations. The dropout rates in most studies were quite high and as no follow-up information was available on these patients, we assumed in the main analysis that drop out patients had relapsed. Exactly how this assumption might have affected the results of the meta-analysis is unclear. This highlights the importance of following-up patients after they withdraw from a study. The assessment of disease activity was not uniform amongst the primary studies. Whilst 10 of the included studies used the CDAl to measure disease activity, two studies used the Harvey Bradshaw Index (Arber 1995; Cezard 2009). The studies which used CDAl defined relapse as a CDAI > 150 or a variable minimum rise in the CDAl score between 50 and 100 points from baseline along with a CDAI > 150 .

We found no evidence to suggest that more adverse events occurred in patients on 5-ASA agents compared to placebo. Although the reporting of adverse events was somewhat inconsistent across the studies we were able to pool data for the proportion of patients who experienced at least one adverse event, withdrawal due to adverse events and serious adverse events. There was no statistically significant differences between 5-ASA and placebo for any of these outcomes. GRADE analyses indicate that the overall quality of the evidence supporting these outcomes was low.

Different preparations and different doses of 5-ASA were used in the included studies. The doses ranged from $1 \mathrm{~g}$ to $3 \mathrm{~g}$ per day. A linear dose-response relationship has been suggested for 5-ASA agents in the maintenance of remission in ulcerative colitis (Hanauer 2004). None of the included studies compared different doses of 5-ASA, and there was no evidence to suggest that studies which used higher doses of 5-ASA preparations demonstrated greater benefits or more adverse events. There was no strong indication to suggest that more adverse events occurred in patients on 5-ASA agents compared to placebo. Future studies should report adverse events in a more consistent manner.

We found no evidence in this review to suggest that 5-ASA preparations are superior to placebo for the maintenance of medically-induced remission in Crohn's disease. The use of 5ASA agents for the prevention of recurrences following surgery for Crohn's disease was not the subject of this review and has been assessed in a separate systematic review (Gordon 2011).

\section{AUTHORS' CONCLUSIONS}

\section{Implications for practice}

We found no evidence in this review to suggest that 5-ASA preparations are superior to placebo for the maintenance of medically-induced remission in patients with Crohn's disease. The incidence of adverse events did not appear to be different in patients receiving 5-ASA compared with those receiving placebo.

\section{Implications for research}

The effect sizes that were found even when drop-outs were ignored were small. Therefore it appears that additional randomised trials may not be justified. Any further studies of maintenance therapy for Crohn's disease should ensure allocation concealment and complete follow-up of patients, and include more detailed and standardised reporting of safety results. A more uniform way of measuring relapse should also be adopted.

\section{A CK N OWLEDGEMENTS}

Partial funding for the Cochrane IBD Group (April 1, 2016 - March 31, 2018) has been provided by Crohn's and Colitis Canada (CCC). 


\section{R E F E R E N C E S}

\section{References to studies included in this review}

Anonymous 1990 \{published data only\}

Anonymous. Coated oral 5-aminosalicylic acid versus placebo in maintaining remission of inactive Crohn's disease. International Mesalazine Study Group. Alimentary Pharmacology and Therapeutics 1990;4(1):55-64.

Arber 1995 \{published data only\}

* Arber N, Odes HS, Fireman Z, Lavie A, Broide E, Bujanover Y, et al. A controlled double blind multicenter study of the effectiveness of 5-aminosalicylic acid in patients with Crohn's disease in remission. Journal of Clinical Gastroenterology 1995;20(3):203-6.

Arber N, Odes SH, Fireman Z, Lavie A, Broide E, Bujanover Y, et al. A controlled double blind multicenter study of the effectiveness of 5-aminosalicylic acid in patients with Crohn's disease in remission. Gastroenterology 1994;106(4 Part 2):A646.

\section{Bondesen 1991 \{published data only\}}

Bondesen S, the Danish 5-ASA group. Mesalazine (Pentasa) as prophylaxis in Crohn's disease. A multicenter, controlled trial. Scandinavian Journal of Gastroenterology 1991;26:68.

\section{Cezard 2009 \{published data only\}}

* Cezard JP, Munck A, Mouterde O, Morali A, Lenaerts C, Lachaux A, et al. Prevention of relapse by mesalazine (Pentasa) in pediatric Crohn's disease: a multicenter, double-blind, randomized, placebo-controlled trial. Gastroenterologie Clinique et Biologique 2009;33:31-40.

Cezard JP, Munck A, Mouterde O, Morali A, Lenaerts C, Lachaux $A$, et al. Prevention of recurrence by mesalamine (PENTASA) in pediatric Crohn's disease. A multicentric double blind trial. Journal of Pediatric Gastroenterology and Nutrition 2003;36:542.

\section{De Franchis 1997 \{published data only\}}

de Franchis R, Brignola C, Del Piano M, Omodei P, Pera A, Ranzi T, et al. Oral 5-aminosalicylic acid (5-ASA) in the prevention of early relapse of Crohn's disease. Interim analysis of a multicenter double blind randomized placebo-controlled trial. Gastroenterology 1994;106:A670.

* de Franchis R, Omodei P, Ranzi T, Brignola C, Rocca R, Prada A, et al. Controlled trial of oral 5-aminosalicylic acid for the prevention of early relapse in Crohn's disease. Alimentary Pharmacology and Therapeutics 1997;11:845-52.

\section{Gendre 1993 \{published data only\}}

Gendre JP, Mary JY, Florent C, Modigliani R, Colombel JF, Soule JC, et al. Maintenance treatment of Crohn's disease using orally administered mesalazine (Pentasa). A controlled multicenter study. Annals of Gastroenterology and Hepatology 1993;29(5):251-6.

* Gendre JP, Mary JY, Florent C, Modigliani R, Colombel JF, Soule JC, et al. Oral mesalamine (Pentasa) as maintenance treatment in Crohn's disease: a multicenter placebo-controlled study. The Groupe d'Etudes Therapeutiques des Inflammatoires Digestives (GETAID). Gastroenterology 1993;104(2):435-9.

\section{Mahmud 2001 \{published data only\}}

Mahmud N, Kamm MA, Dupas JL, Jewell DP, O'Morain CA, Weir DG, et al. Olsalazine is not superior to placebo in maintaining remission of inactive Crohn's colitis and ileocolitis: a double blind, parallel, randomised, multicentre study. Gut 2001;49(4):552-6.

\section{Modigliani 1996 \{published data only\}}

Modigliani R, Colombel JF, Dupas JL, Dapoigny M, Costil V, Veyrac M, et al. Mesalamine in Crohn's disease with steroidinduced remission: effect on steroid withdrawal and remission maintenance. Gastroenterology 1996;110:688-93.

Prantera 1992 \{published data only\}

Prantera C, Pallone F, Brunetti G, Cottone M, Miglioli M. Oral 5aminosalicylic acid (Asacol) in the maintenance treatment of Crohn's disease. The Italian IBD Study Group. Gastroenterology 1992;103(2):363-8.

\section{Sutherland 1997 \{published data only\}}

Sutherland LR, Martin F, Bailey RJ, Fedorak R, Dallaire C, Rossman R, et al. 5-aminosalicylic acid (Pentasa) in the maintenance of remission of Crohn's disease. Gastroenterology 1995;108(4 Suppl 1):A924.

* Sutherland LR, Martin F, Bailey RJ, Fedorak RN, Poleski M, Dallaire C, et al. A randomized, placebo-controlled, double-blind trial of mesalamine in the maintenance of remission of Crohn's disease. The Canadian Mesalamine for Remission of Crohn's Disease Study Group. Gastroenterology 1997;112(4):1069-77.

Thomson 1995 \{published data only\}

Thomson AB, Wright JP, Vatn M, Bailey RJ, Rachmilewitz D, Adler M, et al. Mesalazine (Mesasal/Claversal) $1.5 \mathrm{~g}$ b.d. vs. placebo in the maintenance of remission of patients with Crohn's disease. Alimentary Pharmacology and Therapeutics 1995;9(6):673-83

\section{Wellman 1988 \{published data only\}}

Wellmann W, Schroeder U. New oral preparations for maintenance therapy in Crohn's disease. Canadian Journal of Gastroenterology 1988;2:71A-72A.

\section{References to studies excluded from this review}

\section{Anthonisen 1974 \{published data only\}}

* Anthonisen P, Barany F, Folkenborg O, Holtz A, Jarnum S, Kristensen $M$. The clinical effect of salazosulphapyridine (Salazopyrin r) in Crohn's disease. A controlled double-blind study. Scandinavian Journal of Gastroenterology 1974;9:549-54.

Anthonisen P, Barany F, Folkenborg O, Holtz A, Jarnum S, Kristensen $\mathrm{M}$, et al. Clinical effect of salazosulfapyridine (salazopyrin) in Crohn's disease. A controlled double-blind investigation. Ugeskrift for Laeger 1974;136(32):1798-1802. 
Bresci 1991 \{published data only\}

Bresci G, Petrucci A, Banti S. 5-aminosalicylic acid in the prevention of relapses of Crohn's disease in remission: a longterm study. International Journal of Clinical Pharmacology Research 1991;11(4):200-2.

\section{Bresci 1994 \{published data only\}}

Bresci G, Parisi G, Banti S. Long-term therapy with 5aminosalicylic acid in Crohn's disease: is it useful? Our four years experience. International Journal of Clinical Pharmacology Research 1994;14(4):133-8.

\section{Brignola 1992 \{published data only\}}

Brignola C, Iannone P, Pasquali S, Campieri M, Gionchetti P, Belluzzi A, et al. Placebo-controlled trial of oral 5-ASA in relapse prevention of Crohn's disease. Digestive Diseases and Sciences 1992;37(1):29-32.

\section{Camma 1997 \{published data only\}}

Camma C, Giunta M, Rosselli M, Cottone M. Mesalamine in the maintenance treatment of Crohn's disease: a metaanalysis adjusted for confounding variables. Gastroenterology 1997;113(5):1465-73.

\section{Ewe 1976 \{published data only\}}

Ewe K, Holtermüller KH, Baas U, Eckhart V, Krieg H, Kutzner J, et al. Prevention of recurrence by salazosulfapyridine (azulfidine) therapy in Crohn's disease. A double blind study. Verhandlungen der Deutschen Gesellschaft fur Innere Medizin 1976;82:930-2.

\section{Hanauer 1993 \{published data only\}}

Hanauer SB, Krawitt EL, Robinson M, Rick GG, Safdi MA. Longterm management of Crohn's disease with mesalamine capsules (Pentasa). Pentasa Crohn's Disease Compassionate Use Study Group. American Journal of Gastroenterology 1993;88(9):1343-51.

\section{Lennard-Jones 1977 \{published data only\}}

Lennard-Jones JE. Sulphasalazine in asymptomatic Crohn's disease. Gut 1977;18:69-72.

\section{Lichtenstein 2009 \{published data only\}}

Lichtenstein GR, Ramsey D. Experience with delayed-release mesalamine for maintenance of remission of Crohn's disease (CD). Gastroenterology 2009;1:A661-2.

\section{Luthra 2002 \{published data only\}}

Luthra G, Pasricha PJ. Olsalazine was not better than placebo in maintaining remission in inactive Crohn disease. ACP Journal Club 2002;136(3):92.

\section{Malchow 1981 \{published data only\}}

Malchow H. Further controlled trials of salazosulfapyridine in Crohn's disease. Zeitschrift fur Gastroenterologie 1981;19(Suppl):45-9.

\section{Malchow 1984 \{published data only\}}

Malchow H, Ewe K, Brandes JW. European cooperative Crohn's disease study (ECCDS): Results of drug treatment. Gastroenterology 1984;86(2):249-66.

\section{Nakshabendi 1992 \{published data only\}}

Nakshabendi IM, Duncan A, Russell RI. Is Asacol as effective as sulphasalazine in maintaining remission of Crohn's disease and ulcerative colitis?. Postgraduate Medical Journal 1992;68(797):189-91.

\section{Schreiber 1994 \{published data only\}}

Howaldt S, Raedler A, Reinecker HC, Berghaus D, Hoyer S, Kaiser B. Comparative trial of remission prophylaxis in quiescent Crohn's disease with oral 4-aminosalicylic acid versus 5-aminosalicylic acid slow release tablets. Canadian Journal of Gastroenterology 1993;7:241-4.

Schreiber S, Howaldt S, Guth S, Reinecker HC, Kaiser B, Hoyer S, et al. Maintenance treatment of Crohn's disease: comparative study of 4-aminosalicylic acid and 5-aminosalicylic acid (Claversal) slow release tablets. Gastroenterology 1992;102(Issue 4 Part 2):A692.

* Schreiber S, Howaldt S, Raedler A. Oral 4-aminosalicylic acid versus 5 -aminosalicylic acid slow release tablets. Double blind, controlled pilot sutdy in the maintenance treatment of Crohn's ileocolitis. Gut 1994;35(8):1081-5.

Summers 1979 \{published data only\}

Singleton JW. Results of treatment with sulfasalazine in the American Multicenter Study on the treatment of Crohn disease (National Cooperative Crohn's Disease Study). Zeitschrift fur Gastroenterologie. Verhandlungsband 1981;19:38-40.

Summers RW, Singleton JW. National cooperative Crohn's disease study (NCCDS): a controlled prospective trial of three drugs vs placebo. Gut 1977;18(11):A972-3.

* Summers RW, Switz DM, Sessions JT, Becktel JM, Best WR, Kern F. National Cooperative Crohn's Disease Study: results of drug treatment. Gastroenterology 1979;77(4):847-69.

\section{Additional references}

\section{Azad Khan 1977}

Azad Khan AK, Piris J, Truelove SC. An experiment to determine the active therapeutic moiety of sulphasalazine. Lancet 1977;2(8044):892-5.

\section{Biancone 2003}

Biancone L, Tosti C, Fina D, Fantini M, De Nigris F, Geremia A, et al. Review article: maintenance treatment of Crohn's disease. Alimentary Pharmacology and Therapeutics 2003;17 Suppl 2:31-7.

\section{Das 1973}

Das KM, Eastwood MA, McManus JP, Sircus W. Adverse reactions during salicylazosulfapyridine therapy and the relation with drug metabolism and acetylator phenotype. New England Journal of Medicine 1973;289(10):491-5.

\section{Feagan 2000}

Feagan BG, Fedorak RN, Irvine EJ, Wild G, Sutherland L, Steinhart AH, et al. A comparison of methotrexate with placebo for the maintenance of remission in Crohn's disease. North 
American Crohn's Study Group Investigators. New England Journal of Medicine 2000;342(22):1627-32.

\section{Feagan 2003}

Feagan BG. Maintenance therapy for inflammatory bowel disease. American Journal of Gastroenterology 2003;98(12 Suppl):S6-S17.

\section{Gordon 2011}

Gordon M, Naidoo K, Thomas AG, Akobeng AK. Oral 5aminosalicylic acid for maintenance of surgically-induced remission in Crohn's disease. Cochrane Database of Systematic Reviews 2011, Issue 1. [DOI: 10.1002/14651858.CD008414.pub2]

\section{Guyatt 2008}

Guyatt GH, Oxman AD, Vist GE, Kunz R, Falck-Ytter Y, AlonsoCoello $P$, et al. GRADE: an emerging consensus on rating quality of evidence and strength of recommendations. $B M J$ 2008;336(7650):924-6.

\section{Hanauer 2002}

Hanauer SB, Feagan BG, Lichtenstein GR, Mayer LF, Schreiber S, Colombel JF, et al. Maintenance infliximab for Crohn's disease: the ACCENT I randomised trial. Lancet 2002;359(9317):1541-9.

\section{Hanauer 2004}

Hanauer SB. Review article: aminosalicylates in inflammatory bowel disease. Alimentary Pharmacology and Therapeutics 2004;20 Suppl 4:60-5.

\section{Higgins 2011}

Higgins JPT, Altman DG, Sterne JAC (editors). Chapter 8: Assessing risk of bias in included studies. In: Higgins JPT, Green S editor(s). Cochrane Handbook for Systematic Reviews of Interventions Version 5.1.0 (updated March 2011). The Cochrane Collaboration, 2011. Available from www.cochranehandbook.org.

\section{Klotz 1980}

Klotz U, Maier K, Fischer C, Heinkel K. Therapeutic efficacy of sulfasalazine and its metabolites in patients with ulcerative colitis and Crohn's disease. New England Journal of Medicine 1980;303(26):1499-502.

\section{Lichtenstein 2004}

Lichtenstein GR, Yan S, Bala M, Hanauer S. Remission in patients with Crohn's disease is associated with improvement in employment and quality of life and a decrease in hospitalizations and surgeries. American Journal of Gastroenterology 2004;99(1):91-6.

\section{Messori 1994}

Messori A, Brignola C, Trallori G, Rampazzo R, Bardazzi G, Belloli $C$, et al. Effectiveness of 5-aminosalicylic acid for maintaining remission in patients with Crohn's disease: a meta-analysis. American Journal of Gastroenterology 1994;89(5):692-8.

\section{Myers 1987}

Myers B, Evans DN, Rhodes J, Evans BK, Hughes BR, Lee MG, et al. Metabolism and urinary excretion of 5 -amino salicylic acid in healthy volunteers when given intravenously or released for absorption at different sites in the gastrointestinal tract. Gut 1987;28(2):196-200.

\section{Rutgeerts 1999}

Rutgeerts P, D'Haens G, Targab S, Vasiliauskas E, Hanauer SB, Present $\mathrm{DH}$, et al. Efficacy and safety of retreatment with anti-tumor necrosis factor antibody (infliximab) to maintain remission in Crohn's disease. Gastroenterology 1999;117(4):761-9.

\section{Sandborn 2003}

Sandborn WJ. Evidence-based treatment algorithm for mild to moderate Crohn's disease. American Journal of Gastroenterology 2003;98(12 Suppl):S1-5.

\section{Sands 2004}

Sands BE, Anderson FH, Bernstein CN, Chey WY, Feagan BG, Fedorak RN, et al. Infliximab maintenance therapy for fistulizing Crohn's disease. New England Journal of Medicine 2004;350(9):876-85.

\section{Schroder 1972}

Schroder H, Evans DA. Acetylator phenotype and adverse effects of sulphasalazine in healthy subjects. Gut 1972;13(4):278-84.

\section{Schünemann 2011}

Schünemann HJ, Oxman AD, Vist GE, Higgins JPT, Deeks JJ, Glasziou P, et al. Chapter 12: Interpreting results and drawing conclusions. In: Higgins JPT, Green S editor(s). Cochrane Handbook for Systematic Reviews of Interventions Version 5.1.0 (updated March 2011). The Cochrane Collaboration, 2011. Available from www.cochrane-handbook.org.

\section{Steinhart 1994}

Steinhart AH, Hemphill D, Greenberg GR. Sulfasalazine and mesalazine for the maintenance therapy of Crohn's disease: a meta-analysis. American Journal of Gastroenterology 1994;89(12):2116-24.

\section{Steinhart 2003}

Steinhart AH, Ewe K, Griffiths AM, Modigliani R, Thomsen OO. Corticosteroids for maintenance of remission in Crohn's disease. Cochrane Database of Systematic Reviews 2003, Issue 4. [DOI: 10.1002/14651858.CD000301]

\section{Svartz 1942}

Svartz N. Salazopyrin, a new sulfanilamide preparation: A. Therapeutic results in rheumatic polyarthritis. B. Therapeutic results in ulcerative colitis. $C$. Toxic manifestations in treatment with sulfanilamide preparation. Acta Medica Scandinavica 1942;110:557-90.

\section{van Hees 1980}

van Hees PA, Bakker JH, van Tongeren JH. Effect of sulphapyridine, 5-aminosalicylic acid, and placebo in patients with idiopathic proctitis: a study to determine the active therapeutic moiety of sulphasalazine. Gut 1980;21(7):632-5. 


\section{Wang 2016}

Wang Y, Parker CE, Feagan BG, MacDonald JK. Oral 5aminosalicylic acid for maintenance of remission in ulcerative colitis. Cochrane Database of Systematic Reviews 2016, Issue 5. [DOI: 10.1002/14651858.CD000544.pub4]

\section{References to other published versions of this review}

\section{Akobeng 2005}

Akobeng AK, Gardener E. Oral 5-aminosalicylic acid for maintenance of medically-induced remission in Crohn's disease. Cochrane Database of Systematic Reviews 2005, Issue 1. [DOI: 10.1002/14651858.CD003715.pub2]

* Indicates the major publication for the study

\section{CHARACTERISTICS OF STUDIES}

Characteristics of included studies [ordered by study ID]

Anonymous 1990

\begin{tabular}{|c|c|}
\hline Methods & Randomised, double blind, placebo-controlled multicentre trial \\
\hline \multirow[t]{3}{*}{ Participants } & $\begin{array}{l}248 \text { patients with clinically inactive Crohn's disease at entry }(C D A I<150) \text { - no age or CD location restric- } \\
\text { tions reported }\end{array}$ \\
\hline & Crohn's disease had to be 'controlled' for at least 1 month prior to entry \\
\hline & Controlled described as no steroids or a stable low dose (prednisone $2.5 \mathrm{mg} /$ day or less) \\
\hline \multirow[t]{2}{*}{ Interventions } & Oral 5-ASA (Mesasal / Claversal, Smith Kline \& French company) at a dose of $1.5 \mathrm{~g} / \mathrm{day}(\mathrm{n}=125)$ \\
\hline & Placebo $(n=123)$ \\
\hline \multirow[t]{2}{*}{ Outcomes } & Primary outcome: relapse at 12 months (CDAl > 150 and an increase in CDAl of 60 points from baseline) \\
\hline & Secondary outcomes: adverse events, withdrawal due to adverse events \\
\hline
\end{tabular}

\section{Risk of bias}

\begin{tabular}{|c|c|c|}
\hline Bias & Authors' judgement & Support for judgement \\
\hline $\begin{array}{l}\text { Random sequence genera- } \\
\text { tion (selection bias) }\end{array}$ & Low risk & Quote: "predetermined computer-generated list" \\
\hline $\begin{array}{l}\text { Allocation concealment } \\
\text { (selection bias) }\end{array}$ & Low risk & $\begin{array}{l}\text { Quote: "Drug supplies were centrally packaged, labelled and randomized in } \\
\text { blocks of four according to a predetermined computer-generated list" }\end{array}$ \\
\hline $\begin{array}{l}\text { Blinding of participants } \\
\text { and personnel (perfor- } \\
\text { mance bias) } \\
\text { All outcomes }\end{array}$ & Low risk & $\begin{array}{l}\text { Double-blind study } \\
\text { Quote: "patients were randomly allocated to treatment with one of the follow- } \\
\text { ing regiments: 5-ASA, or matching placebo for 5-ASA" }\end{array}$ \\
\hline $\begin{array}{l}\text { Blinding of outcome as- } \\
\text { sessment (detection bias) } \\
\text { All outcomes }\end{array}$ & Low risk & Patient and physician assessed outcomes were blinded \\
\hline $\begin{array}{l}\text { Incomplete outcome data } \\
\text { (attrition bias) } \\
\text { All outcomes }\end{array}$ & Low risk & $\begin{array}{l}\text { Drop-outs balanced across intervention groups with similar reasons for with- } \\
\text { drawal }\end{array}$ \\
\hline $\begin{array}{l}\text { Selective reporting (re- } \\
\text { porting bias) }\end{array}$ & Unclear risk & $\begin{array}{l}\text { Although some subgroup analyses were not prespecified these analyses would } \\
\text { generally be expected for this type of study }\end{array}$ \\
\hline
\end{tabular}


Anonymous 1990 (Continued)

Other bias Low risk The study appears to be free of other sources of bias

Arber 1995

Methods Randomised, double blind, placebo-controlled multicentre trial

Participants

59 patients with Crohn's disease in continuous remission for at least 6 months - patients could have Crohn's disease of the small bowel, large bowel or both - no age restrictions were reported

Remission was defined as a Harvey Bradshaw (Softley-Clamp modification) index score of $<4$

Patients could be treated with only 5-ASA or sulphasalazine within last 6 months

\begin{tabular}{ll}
\hline Interventions & Oral 5-ASA (Rafassal similar to Salofalk/Claversal, Rafia Laboratory, Israel) at a dose of $1 \mathrm{~g} / \mathrm{day}(\mathrm{n}=28)$ \\
& Placebo $(\mathrm{n}=31)$ \\
\hline Outcomes & Primary outcome: relapse at 12 months (increase of more than 4 points on the index from baseline) \\
& Secondary outcomes: adverse events, withdrawal due to adverse events \\
\hline
\end{tabular}

Notes

\section{Risk of bias}

\begin{tabular}{|c|c|c|}
\hline Bias & Authors' judgement & Support for judgement \\
\hline $\begin{array}{l}\text { Random sequence genera- } \\
\text { tion (selection bias) }\end{array}$ & Low risk & Computer-generated list \\
\hline $\begin{array}{l}\text { Allocation concealment } \\
\text { (selection bias) }\end{array}$ & Low risk & $\begin{array}{l}\text { Quote: "coding and randomization were performed by a central pharmacy that } \\
\text { dispensed the coded medicines to the participating centers" }\end{array}$ \\
\hline $\begin{array}{l}\text { Blinding of participants } \\
\text { and personnel (perfor- } \\
\text { mance bias) } \\
\text { All outcomes }\end{array}$ & Low risk & $\begin{array}{l}\text { Double-blind study } \\
\text { Quote: "Patients were given coded mesalazine or placebo four tablets/day } \\
\text { (coated 5-ASA preparation similar to Salofalk-Claversal)" }\end{array}$ \\
\hline
\end{tabular}

Blinding of outcome as- Low risk Patient and physician assessed outcomes were blinded

sessment (detection bias)

All outcomes

$\begin{array}{ll}\begin{array}{l}\text { Incomplete outcome data } \\ \text { (attrition bias) }\end{array} & \text { Low risk } \\ \text { All outcomes } & \begin{array}{l}\text { Drop-outs balanced across intervention groups with similar reasons for with- } \\ \text { drawal }\end{array} \\ & \begin{array}{l}\text { Quote: "Ten patients were withdrawn from the trial, four from the placebo } \\ \text { group and six from the treatment group. Among these patients, five were with- } \\ \text { drawn because of noncompliance, three patients were lost to follow-up, and } \\ \text { one in each group had side effects (headache) leading to withdrawal from the } \\ \text { study" }\end{array}\end{array}$

\begin{tabular}{|c|c|c|}
\hline $\begin{array}{l}\text { Selective reporting (re- } \\
\text { porting bias) }\end{array}$ & Unclear risk & $\begin{array}{l}\text { Although some subgroup analyses were not prespecified these analyses would } \\
\text { generally be expected for this type of study }\end{array}$ \\
\hline
\end{tabular}

Other bias Low risk The study appears to be free of other sources of bias


Bondesen 1991

\begin{tabular}{ll}
\hline Methods & Randomised, double blind, placebo-controlled multicentre trial \\
\hline Participants & 202 patients with clinically inactive Crohn's disease \\
\hline Interventions & Pentasa $1.5 \mathrm{~g}$ bid $(\mathrm{n}=101)$ \\
& Placebo $(\mathrm{n}=101)$ \\
\hline Outcomes & Primary outcome: relapse at 12 to 18 months \\
& Seconadry outcome: adverse events \\
\hline Notes & Abstract publication
\end{tabular}

\section{Risk of bias}

\begin{tabular}{lll}
\hline Bias & Authors' judgement & Support for judgement \\
\hline $\begin{array}{l}\text { Random sequence genera- } \\
\text { tion (selection bias) }\end{array}$ & Unclear risk & Not described \\
\hline $\begin{array}{l}\text { Allocation concealment } \\
\text { (selection bias) }\end{array}$ & Unclear risk & Not described \\
\hline $\begin{array}{l}\text { Blinding of participants } \\
\text { and personnel (perfor- } \\
\text { mance bias) }\end{array}$ & Unclear risk & Quote: "patients were...randomized to active drug or placebo \\
All outcomes & How blinding was achieved was not described in abstract \\
\hline $\begin{array}{l}\text { Blinding of outcome as- } \\
\text { sessment (detection bias) } \\
\text { All outcomes }\end{array}$ & Unclear risk & Not described \\
\hline $\begin{array}{l}\text { Incomplete outcome data } \\
\text { (attrition bias) } \\
\text { All outcomes }\end{array}$ & Unclear risk & Not described \\
\hline $\begin{array}{l}\text { Selective reporting (re- } \\
\text { porting bias) }\end{array}$ & Unclear risk & Not described \\
\hline \begin{tabular}{l} 
Other bias \\
\hline
\end{tabular} & Unclear risk & Unclear from abstract \\
\hline
\end{tabular}

Cezard 2009

\begin{tabular}{ll}
\hline Methods & $\begin{array}{l}\text { Randomised, double-blind, placebo-controlled, multicenter trial performed in } 17 \text { centres (16 from } \\
\text { France and } 1 \text { from Switzerland) for one year } \\
\text { Data was analysed following an intention-to-treat analysis }\end{array}$ \\
\hline Participants & $\begin{array}{l}\text { Patients ( } N=132) \text { under the age of } 18 \text { and diagnosed with CD before the age of 16, according to clinical, } \\
\text { radiological, endoscopic and histological data }\end{array}$ \\
& $\begin{array}{l}\text { Specific inclusion criteria: patients in clinical remission within six months of flare-up treatment started } \\
\text { prior to inclusion, with an HB score inferior to 5, ESR superior to 25mm, and normal hepatic and renal } \\
\text { function }\end{array}$
\end{tabular}


Cezard 2009 (Continued)

Specific exclusion criteria: patients were excluded if a flare-up had been treated with mesalazine or immunosuppressants, or if they had a known hypersensitivity to salicylate

\begin{tabular}{ll}
\hline Interventions & $50 \mathrm{mg} / \mathrm{kg}$ mesalazine or placebo over a 1 year period \\
\hline Outcomes & $\begin{array}{l}\text { Primary outcome: clinical relapse (HB score greater than or equal to 5, confirmed within two weeks) or } \\
\text { surgery for acute complication of CD } \\
\text { Secondary outcome: treatment failure, defined as relapse, failure of steroid withdrawal, side-effect in- } \\
\text { tolerance requiring treatment discontinuation, worsening or aggravation of patient's status requiring } \\
\text { treatment }\end{array}$ \\
\hline
\end{tabular}

Notes

\section{Risk of bias}

\begin{tabular}{lll}
\hline Bias & Authors' judgement & Support for judgement \\
\hline $\begin{array}{l}\text { Random sequence genera- } \\
\text { tion (selection bias) }\end{array}$ & Low risk & $\begin{array}{l}\text { Randomization sequence was generated by a third-party } \\
\text { Quote: "the randomization lists were generated by the randomization center" }\end{array}$ \\
& $\begin{array}{l}\text { Quote: "patients were randomized by stratum within each center, using ran- } \\
\text { domized blocks of two to four) }\end{array}$ \\
\hline
\end{tabular}

Allocation concealment Low risk Centralized randomisation performed by a third party

(selection bias)

Quote: "At randomization, a chronological treatment number was assigned to each patient and, accordingly, the treatment allocated to each patient was given to the physician in charge of that patient in numbered bottles, labeled with the protocol identification, center and stratum, patient's initials, treatment number, batch number and expiry date"

\begin{tabular}{ll}
\hline $\begin{array}{l}\text { Blinding of participants } \\
\text { and personnel (perfor- }\end{array}$ & Low risk \\
$\begin{array}{l}\text { mance bias) } \\
\text { All outcomes }\end{array}$ & Double-blind study \\
& $\begin{array}{l}\text { Intervention and placebo tablets were identical } \\
\text { Quote: "Each allocated treatment was sent to the physician in charge of that } \\
\text { patient in an individual sealed envelope" }\end{array}$
\end{tabular}

Blinding of outcome as- Low risk Patient and physician assessed outcomes were blinded

sessment (detection bias)

All outcomes

\begin{tabular}{|c|c|c|}
\hline $\begin{array}{l}\text { Incomplete outcome data } \\
\text { (attrition bias) } \\
\text { All outcomes }\end{array}$ & Low risk & $\begin{array}{l}\text { Drop-outs were similar across intervention groups with similar reasons for } \\
\text { withdrawal } \\
\text { Low proportion of withdrawals per group }\end{array}$ \\
\hline $\begin{array}{l}\text { Selective reporting (re- } \\
\text { porting bias) }\end{array}$ & Low risk & All expected outcomes were reported \\
\hline Other bias & Low risk & The study appears to be free of other sources of bias \\
\hline
\end{tabular}

\section{De Franchis 1997}

Methods

Randomized, double-blind, placebo-controlled, multicentre trial conducted at 22 institutions. Data was analysed following an intention-to-treat 
De Franchis 1997 (Continued)

Participants
Specific inclusion criteria: patients with an established diagnosis of Crohn's disease localized to the ileum, colon or both with endoscopic, radiological and/or surgical confirmation of disease location within 1 year prior to enrolment; if they had an acute flare-up of the disease (CDAI > 150 and $\leq 450$ ); if they had achieved remission with a standard steroid-dose regiment; and if they were between 18 and 70 years of age.

Specific exclusion criteria: patients who had oesophageal, gastroduodenal or jejunal localizations of Crohn's disease, clinically significant bowel stenosis, fistulas requiring metronidazole treatment or surgery, or other active extra-intestinal manifestations requiring steroid treatment; if they had been treated with steroids or immunosuppressants within 3 months of enrolment; if they had clinically sig-

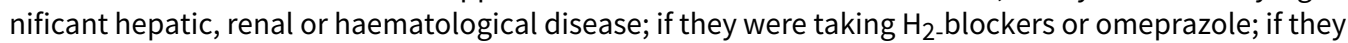
were allergic to salicylates; or if they were pregnant or lactating women according to a standard dose regimen (methylprednisolone, $1 \mathrm{mg} / \mathrm{kg}$ q.d.s with a maximum of $60 \mathrm{mg}$ q.d.s. given orally for 4-8 weeks). Those who achieved clinical remission (CDAl $<150)$ were entered into the study. Six tablets, administered in three daily doses, containing either 5-ASA (Claversal) $500 \mathrm{mg}$ or a placebo. Daily steroid dose was tapered by $0.25 \mathrm{mg} / \mathrm{kg}$ every two weeks once this regiment was started

Two outcomes were assessed:
i) clinical relapse, defined as an increase of CDAl above 150 and at least 60 points above the value ob-
served at achievement of remission, accompanied by an increase of at least two of the three acute-
phase reactants (ESR, alpha-1 acid glycoprotein and alpha-2 globulins)

ii) completion of a 24-month study period without clinical relapse

Notes

\section{Risk of bias}

\begin{tabular}{|c|c|c|}
\hline Bias & Authors' judgement & Support for judgement \\
\hline $\begin{array}{l}\text { Random sequence genera- } \\
\text { tion (selection bias) }\end{array}$ & Unclear risk & $\begin{array}{l}\text { Procedure used for randomisation not described } \\
\text { Quote: "randomization was done centrally in blocks of four" }\end{array}$ \\
\hline $\begin{array}{l}\text { Allocation concealment } \\
\text { (selection bias) }\end{array}$ & Low risk & $\begin{array}{l}\text { Central randomisation } \\
\text { Quote: "randomization was done centrally in blocks of four" }\end{array}$ \\
\hline $\begin{array}{l}\text { Blinding of participants } \\
\text { and personnel (perfor- } \\
\text { mance bias) } \\
\text { All outcomes }\end{array}$ & Low risk & $\begin{array}{l}\text { Double-blind, randomised, placebo-controlled trial } \\
\text { Placebo pills were identical to 5-ASA pills }\end{array}$ \\
\hline $\begin{array}{l}\text { Blinding of outcome as- } \\
\text { sessment (detection bias) } \\
\text { All outcomes }\end{array}$ & Unclear risk & Not described \\
\hline $\begin{array}{l}\text { Incomplete outcome data } \\
\text { (attrition bias) } \\
\text { All outcomes }\end{array}$ & Low risk & $\begin{array}{l}\text { Drop-outs balanced across intervention groups with similar reasons for with- } \\
\text { drawal } \\
\text { Quote: "Seventeen patients (eight on 5-ASA and nine on placebo) were with- } \\
\text { drawn from the study: } 15 \text { of them were lost to follow-up, one was considered } \\
\text { as non-compliant, one required surgery for ileorectal fistula". }\end{array}$ \\
\hline $\begin{array}{l}\text { Selective reporting (re- } \\
\text { porting bias) }\end{array}$ & Unclear risk & $\begin{array}{l}\text { Although some subgroup analyses were not prespecified these analyses would } \\
\text { generally be expected for this type of study }\end{array}$ \\
\hline
\end{tabular}


De Franchis 1997 (Continued)
Other bias
Low risk
The study appears to be free of other sources of bias

Gendre 1993

$\begin{array}{ll}\text { Methods } & \text { Multicentre study. Described as randomised:Yes Randomisation method described:No Described as } \\ \text { double blind:Yes Blind method described:No Follow-ups described:Yes } \\ \text { Strata: High relapse risk stratum (remission for }<3 \text { months) and Low relapse risk stratum (remission for } \\ 3-24 \text { months) }\end{array}$

\begin{tabular}{ll}
\hline Participants & Inclusion criteria: Age greater than 15. CD of the small bowel, colon or both. CD in remission $<24$ \\
months. Remission defined as CDAI $<150$. No steroid use in month before trial.
\end{tabular}

\begin{tabular}{ll}
\hline Interventions & $\begin{array}{l}\text { Oral 5-ASA vs placebo. Allocation: } 80 \text { patients allocated to 5-ASA, and } 81 \text { patients allocated to placebo. } \\
\text { Name 5-ASA: Pentasa. Manufacturer: Ferring AS, Vanlose, Denmark. Dose: } 2 \mathrm{~g} \text { per day }\end{array}$ \\
\hline Outcomes & $\begin{array}{l}\text { Relapse measured at: } 24 \text { months. Definition of relapse: Surgery or CDAI >250 or CDAl between } 150 \text { and } \\
250 \text { but over the baseline value by }>50 \text { points. }\end{array}$
\end{tabular}

Notes

\section{Risk of bias}

\begin{tabular}{|c|c|c|}
\hline Bias & Authors' judgement & Support for judgement \\
\hline $\begin{array}{l}\text { Random sequence genera- } \\
\text { tion (selection bias) }\end{array}$ & Unclear risk & Not described \\
\hline $\begin{array}{l}\text { Allocation concealment } \\
\text { (selection bias) }\end{array}$ & Unclear risk & Not described \\
\hline $\begin{array}{l}\text { Blinding of participants } \\
\text { and personnel (perfor- } \\
\text { mance bias) } \\
\text { All outcomes }\end{array}$ & Low risk & $\begin{array}{l}\text { Quote: "the study followed a randomized, double-blind, stratified design" } \\
\text { Identical Pentasa and placebo tablets used }\end{array}$ \\
\hline $\begin{array}{l}\text { Blinding of outcome as- } \\
\text { sessment (detection bias) } \\
\text { All outcomes }\end{array}$ & Low risk & Patient and physician assessed outcomes were blinded \\
\hline $\begin{array}{l}\text { Incomplete outcome data } \\
\text { (attrition bias) } \\
\text { All outcomes }\end{array}$ & Low risk & $\begin{array}{l}\text { Drop-outs balanced across intervention groups with similar reasons for with- } \\
\text { drawal }\end{array}$ \\
\hline $\begin{array}{l}\text { Selective reporting (re- } \\
\text { porting bias) }\end{array}$ & Unclear risk & $\begin{array}{l}\text { Although some subgroup analyses were not prespecified these subgroup } \\
\text { analyses would generally be expected for this type of study }\end{array}$ \\
\hline Other bias & Low risk & The study appears to be free of other sources of bias \\
\hline
\end{tabular}

Mahmud 2001

$\begin{array}{ll}\text { Methods } & \text { Multicentre study. Described as randomised:Yes Randomisation method described:Yes Described as } \\ \text { double blind:Yes Blind method described:No Follow-ups described:Yes }\end{array}$

double blind:Yes Blind method described:No Follow-ups described:Yes 
Mahmud 2001 (Continued)

Participants

Inclusion criteria: Age greater than 18. CD of the colitis, ileitis or both. CD in remission for 1 month prior to randomisation. Remission was defined as assessed by investigator and by CDAI $<150$. No steroid use one month prior to study.

Interventions Oral 5-ASA vs placebo. Allocation: 167 patients allocated to 5-ASA, and 161 patients allocated to placebo. Name 5-ASA: Olsalazine. Manufacturer: Kabi Pharmacia. Dose: 2 g per day

Outcomes

Relapse measured at: 12 months. Definition of relapse: CDAI $>150$ or an increase in the CDAI score by 60 or more from the baseline score at week 0 or clinical relapse (need for additional therapy or surgery).

Notes

\section{Risk of bias}

Bias Authors' judgement Support for judgement

Random sequence genera- Low risk Quote: "computer generated randomization"

tion (selection bias)

\begin{tabular}{lll}
\hline $\begin{array}{l}\text { Allocation concealment } \\
\text { (selection bias) }\end{array}$ & Unclear risk & Not described \\
\hline $\begin{array}{l}\text { Blinding of participants } \\
\text { and personnel (perfor- } \\
\text { mance bias) }\end{array}$ & Low risk & Quote: "the trial was randomised, double-blind, parallel study" \\
All outcomes & & Quote: "Identical placebos were provided by Kabi Pharmacia"
\end{tabular}

Alloutcomes

Blinding of outcome as- Low risk

Patient and physician assessed outcomes were blinded

sessment (detection bias)

All outcomes

\begin{tabular}{|c|c|c|}
\hline $\begin{array}{l}\text { Incomplete outcome data } \\
\text { (attrition bias) } \\
\text { All outcomes }\end{array}$ & Unclear risk & $\begin{array}{l}\text { Quote: "More patients in the olsalazine treated group failed to complete a } 52 \\
\text { week treatment period than in the placebo treated group (olsalazine } 65.9 \% \mathrm{v} \\
\text { placebo } 53.4 \% \text { )" }\end{array}$ \\
\hline
\end{tabular}

(attrition bias)

Quote: "the frequency of intolerable adverse events was higher in the ol-

salazine than in the placebo treated group $(19.8 \%$ v $6.2 \%$, respectively)"

\begin{tabular}{lll}
\hline $\begin{array}{l}\text { Selective reporting (re- } \\
\text { porting bias) }\end{array}$ & Low risk & Expected outcomes were reported \\
\hline Other bias & Low risk & The study appears to be free of other sources of bias \\
\hline
\end{tabular}

Modigliani 1996

\begin{tabular}{ll}
\hline Methods & $\begin{array}{l}\text { Randomised, double-blind, stratified study conducted in } 20 \text { Groupe d'Etudes Thérapeutiques des Af- } \\
\text { fections Inflammatoires Digestives (GETAID) centres, } 19 \text { from France and } 1 \text { from Belgium }\end{array}$ \\
\hline Participants & Patients ( $N=129)$ aged 15 years or older with active CD (CDAI > 200) \\
& $\begin{array}{l}\text { Specific inclusion criteria: patients with active CD (CDAI > 200); if they were } 15 \text { years or older with CD } \\
\text { of the small intestine, recto-colon, or both as documented by barium radiographs and/or colonoscopy } \\
\text { within } 12 \text { months before inclusion }\end{array}$ \\
& $\begin{array}{l}\text { Specific exclusion criteria: imminent need for surgery, purely anorectal CD, contraindication to corti- } \\
\text { costeroids, previous hypersensitivity to salicylates or intolerance to mesalamine, and liver or kidney in- } \\
\text { sufficiency; patients in whom mesalamine had clearly failed to maintain remissions (i.e., if the attack }\end{array}$ \\
\hline
\end{tabular}

Oral 5-aminosalicylic acid for maintenance of medically-induced remission in Crohn's disease (Review) 
Modigliani 1996 (Continued)

leading to pre-inclusion had occurred while they were on mesalamine at a daily dose of $>3 \mathrm{~g}$ for more than 2 months)

Interventions

Patients with active CD were pre-included in the study and were administered oral prednisolone (1 $\mathrm{mg} /$ kg once a day) for 3-7 weeks

Patients achieving clinical remission within this time frame were included in the trial and randomly assigned within each centre and stratum to be administered daily either $4 \mathrm{~g}$ of mesalamine (Pentasa) or identical placebo tablets

Prednisolone was tapered in steps of $10 \mathrm{mg}$ per 10 days to a dose of $0.5 \mathrm{mg} / \mathrm{kg} / \mathrm{day}$ and then in steps of $5 \mathrm{mg}$ per 10 days to complete discontinuation

Outcomes

Treatment failure defined as a failure to discontinue steroids (secondary steroid resistance, steroid dependence, or surgery because of $C D$ ) or a relapse (CDAl > 150 and a 100-point increase above inclusion value and/or need for surgery) during the 1-year follow-up

$$
\text { Notes }
$$

\section{Risk of bias}

\begin{tabular}{lll}
\hline Bias & Authors' judgement & Support for judgement \\
\hline $\begin{array}{l}\text { Random sequence genera- } \\
\text { tion (selection bias) }\end{array}$ & Unclear risk & Not described \\
\hline $\begin{array}{l}\text { Allocation concealment } \\
\text { (selection bias) }\end{array}$ & Unclear risk & Not described \\
\hline $\begin{array}{l}\text { Blinding of participants } \\
\text { and personnel (perfor- } \\
\text { mance bias) }\end{array}$ & Low risk & $\begin{array}{l}\text { Quote: "randomized, double-blind, stratified design" } \\
\text { All outcomes }\end{array}$
\end{tabular}

Blinding of outcome as- Low risk Patient and physician assessed outcomes were blinded
sessment (detection bias)

All outcomes

\begin{tabular}{|c|c|c|}
\hline $\begin{array}{l}\text { Incomplete outcome data } \\
\text { (attrition bias) }\end{array}$ & Low risk & $\begin{array}{l}\text { Dropouts were balanced across treatment groups with similar reasons for } \\
\text { withdrawal }\end{array}$ \\
\hline
\end{tabular}

All outcomes withdrawal

Selective reporting (re- Low risk Expected outcomes were reported
porting bias)

Other bias Low risk The study appears to be free of other sources of bias

Prantera 1992

$\begin{array}{ll}\text { Methods } & \text { Multicentre study. Described as randomised:Yes Randomisation method described:Yes Described as } \\ \text { double blind:Yes Blind method described:Yes Follow-ups described:Yes }\end{array}$

$\begin{array}{ll}\text { Participants } & \text { Inclusion criteria: Aged between } 18 \text { and } 65 . \text { CD of the ileum, colon or both. CD in remission between } 3 \\ \text { and } 24 \text { months. Remission defined as CDAI } 150 \text {. No steroid use } 3 \text { months prior to study. }\end{array}$


Prantera 1992 (Continued)

Interventions
Oral 5-ASA vs placebo. Allocation: 64 patients allocated to 5-ASA, and 61 patients allocated to placebo. Name 5-ASA: Asacol. Manufacturer: Giuliani, Milan. Dose: $2.4 \mathrm{~g} /$ day

Outcomes

Relapse measured at: 12 months. Definition of relapse: CDAI > 150 with an increase of 100 points over the baseline value, confirmed at a second visit 1 week later

Notes

\section{Risk of bias}

\begin{tabular}{|c|c|c|}
\hline Bias & Authors' judgement & Support for judgement \\
\hline $\begin{array}{l}\text { Random sequence genera- } \\
\text { tion (selection bias) }\end{array}$ & Low risk & Quote: "computer-generated randomization list" \\
\hline $\begin{array}{l}\text { Allocation concealment } \\
\text { (selection bias) }\end{array}$ & Low risk & Quote: "study medications were centrally packaged" \\
\hline $\begin{array}{l}\text { Blinding of participants } \\
\text { and personnel (perfor- } \\
\text { mance bias) } \\
\text { All outcomes }\end{array}$ & Low risk & $\begin{array}{l}\text { Double-blind study } \\
\text { Quote: "Eligible patients were randomly allocated to receive either 5-ASA or } \\
\text { identical placebo tablets for } 12 \text { months" }\end{array}$ \\
\hline $\begin{array}{l}\text { Blinding of outcome as- } \\
\text { sessment (detection bias) } \\
\text { All outcomes }\end{array}$ & Low risk & Patient and physician assessed outcomes were blinded \\
\hline $\begin{array}{l}\text { Incomplete outcome data } \\
\text { (attrition bias) } \\
\text { All outcomes }\end{array}$ & Low risk & $\begin{array}{l}\text { Quote: "Eight patients, } 5 \text { on } 5-A S A \text { and } 3 \text { on placebo, were withdrawn from the } \\
\text { trial because of adverse reactions" } \\
\text { Quote: "One patient was lost to follow-up. } \\
\text { Quote: "Two patients in the 5-ASA group elected to stop treatment" }\end{array}$ \\
\hline $\begin{array}{l}\text { Selective reporting (re- } \\
\text { porting bias) }\end{array}$ & Unclear risk & $\begin{array}{l}\text { Although some posthoc subgroup analysis performed were not prespecified } \\
\text { these subgroup analyses would generally be expected for this type of study }\end{array}$ \\
\hline Other bias & Low risk & The study appears to be free of other sources of bias \\
\hline
\end{tabular}

\section{Sutherland 1997}

$\begin{array}{ll}\text { Methods } & \text { Multicentre study. Described as randomised:Yes Randomisation method described:Yes Described as } \\ \text { double blind:Yes Blind method described:Yes Follow-ups described:Yes }\end{array}$

Inclusion criteria: Age greater than 18. CD location restrictions not mentioned. CD in remission for 1
month, but at least 2 flare-ups within the last 4 years, one within the last 18 months or a recent resec-
tion. Remission defined as CDAI $<150$ at baseline and no symptoms within last 30 days. No steroid use
within a month of study.

Interventions

Oral 5-ASA vs placebo. Allocation: 141 patients allocated to 5-ASA, and 152 patients allocated to placebo. Name 5-ASA: microsphere coated with ethylcellulose, Mesalamine. Manufacturer: Not provided by authors. Dose: 3 g per day

$\begin{array}{ll}\text { Outcomes } & \text { Relapse measured at: } 12 \text { months. Definition of relapse: } 1 \text { st occurrence of a CDAI that was }>150 \text { as well } \\ \text { as the absolute value of at least } 60 \text { points higher than baseline or where physician diagnosed a flare-up } \\ \text { of disease but a full diary card was not available for the calculation of the final CDAI. }\end{array}$


Sutherland 1997 (Continued)

Notes

\section{Risk of bias}

\begin{tabular}{|c|c|c|}
\hline Bias & Authors' judgement & Support for judgement \\
\hline $\begin{array}{l}\text { Random sequence genera- } \\
\text { tion (selection bias) }\end{array}$ & Low risk & Quote: "computer-generated randomization scheme" \\
\hline $\begin{array}{l}\text { Allocation concealment } \\
\text { (selection bias) }\end{array}$ & Low risk & $\begin{array}{l}\text { Quote: "medication was packaged by the sponsor and dispensed to each cen- } \\
\text { ter in coded identical-appearing boxes }\end{array}$ \\
\hline $\begin{array}{l}\text { Blinding of participants } \\
\text { and personnel (perfor- } \\
\text { mance bias) } \\
\text { All outcomes }\end{array}$ & Low risk & $\begin{array}{l}\text { Double-blind study } \\
\text { Quote: "Medication was dispensed in bottles containing identical appearing } \\
\text { capsules of either } 250 \mathrm{mg} \text { mesalamine or placebo" }\end{array}$ \\
\hline $\begin{array}{l}\text { Blinding of outcome as- } \\
\text { sessment (detection bias) } \\
\text { All outcomes }\end{array}$ & Low risk & $\begin{array}{l}\text { Patient and physician assessed outcomes were blinded } \\
\text { Quote: "the statistical analysis was performed using SAS Version } 6.04 \text { by a } \\
\text { third party" }\end{array}$ \\
\hline $\begin{array}{l}\text { Incomplete outcome data } \\
\text { (attrition bias) } \\
\text { All outcomes }\end{array}$ & Low risk & $\begin{array}{l}\text { Drop-outs balanced across intervention groups with similar reasons for with- } \\
\text { drawal } \\
\text { Quote: "Forty-seven patients were withdrawn within } 28 \text { days after entry in- } \\
\text { to the study. Twenty-five reported a relapse ( } 11 \text { mesalamine-treated and } 14 \\
\text { placebo-treated patients), and } 22 \text { were withdrawn for failure to comply with } \\
\text { the protocol ( } 12 \text { mesalmine and } 10 \text { placebo-treated patients" }\end{array}$ \\
\hline $\begin{array}{l}\text { Selective reporting (re- } \\
\text { porting bias) }\end{array}$ & Unclear risk & $\begin{array}{l}\text { Although some subgroup analyses were not prespecified these analyses would } \\
\text { generally be expected for this type of study }\end{array}$ \\
\hline Other bias & Low risk & The study appears to be free of other sources of bias \\
\hline
\end{tabular}

\section{Thomson 1995}

Multicentre study. Described as randomised:Yes Randomisation method described:Yes Described as
double blind:Yes Blind method described:Yes Follow-ups described:Yes

\section{Participants}

Inclusion criteria: Aged between 18 and $70 . C D$ of the ileum, colon or both. CD in remission but had one period of activity within the previous 28 months. Remission defined as CDAI $<150$. No steroid use within month of study.

Oral 5-ASA vs placebo. Allocation: 102 patients allocated to 5-ASA, and 105 patients allocated to place-
bo. Name 5-ASA: Claversal / Mesasal. Manufacturer: Smith Kline, Beecham. Dose: $1.5 \mathrm{~g}$ b.d

\section{Outcomes}

Relapse measured at: 12 months. Definition of relapse: CDAI > 150 with at least a 60 -point increase from the baseline index score.

Notes Originally presented as 2 parts 'Colitis or ileocolitis' and 'Ileitis'

\section{Risk of bias}


Thomson 1995 (Continued)

\begin{tabular}{lll}
$\begin{array}{l}\text { Random sequence genera- } \\
\text { tion (selection bias) }\end{array}$ & Low risk & Quote: "randomization with Procplan in SAS" \\
\hline $\begin{array}{l}\text { Allocation concealment } \\
\text { (selection bias) }\end{array}$ & Low risk & $\begin{array}{l}\text { All study medications were supplied in blister packets of six tablets which were } \\
\text { indistinguishable from one another }\end{array}$ \\
\hline $\begin{array}{l}\text { Blinding of participants } \\
\begin{array}{l}\text { and personnel (perfor- } \\
\text { mance bias) }\end{array}\end{array}$ & Low risk & Double-blind study \\
All outcomes & $\begin{array}{l}\text { Quote: "All study medications (mesalazine and matching placebo) were sup- } \\
\text { plied in blister packets ...." }\end{array}$
\end{tabular}

\begin{tabular}{lll}
\hline $\begin{array}{l}\text { Blinding of outcome as- } \\
\text { sessment (detection bias) } \\
\text { All outcomes }\end{array}$ & Low risk & Patient and investigator assessed outcomes were blinded \\
\hline $\begin{array}{l}\text { Incomplete outcome data } \\
\text { (attrition bias) }\end{array}$ & Low risk & $\begin{array}{l}\text { Drop-outs balanced across intervention groups with similar reasons for with- } \\
\text { drawal }\end{array}$ \\
All outcomes & $\begin{array}{l}\text { Quote: "106 patients ( } 51 \text { in the mesalazine group and } 55 \text { in the placebo group) } \\
\text { were withdrawn from the study due to adverse events }\end{array}$
\end{tabular}

\begin{tabular}{lll}
\hline $\begin{array}{l}\text { Selective reporting (re- } \\
\text { porting bias) }\end{array}$ & Low risk & Expected outcomes were reported \\
\hline Other bias & Low risk & The study appears to be free of other sources of bias \\
\hline
\end{tabular}

\section{Wellman 1988}

\begin{tabular}{ll}
\hline Methods & Randomised, double-blind, placebo-controlled study conducted for one year \\
\hline Participants & $\begin{array}{l}\text { Patients }(\mathrm{N}=66) \text { with Crohn's disease in remission (CDAI < 150) for at least } 3 \text { months without steroids; } \\
\text { diagnosis was confirmed by characteristic endoscopy or radiologic findings }\end{array}$ \\
\hline Interventions & Study population was randomised to receive mesalazine or placebo in blocks of four patients \\
\hline Outcomes & Number of relapses was assessed. Adverse reactions were also assessed. \\
\hline Notes & \\
\hline
\end{tabular}

\section{Risk of bias}

\begin{tabular}{|c|c|c|}
\hline Bias & Authors' judgement & Support for judgement \\
\hline $\begin{array}{l}\text { Random sequence genera- } \\
\text { tion (selection bias) }\end{array}$ & Unclear risk & Not described \\
\hline $\begin{array}{l}\text { Allocation concealment } \\
\text { (selection bias) }\end{array}$ & Unclear risk & Not described \\
\hline $\begin{array}{l}\text { Blinding of participants } \\
\text { and personnel (perfor- } \\
\text { mance bias) } \\
\text { All outcomes }\end{array}$ & Unclear risk & $\begin{array}{l}\text { Double-blind study } \\
\text { Not described }\end{array}$ \\
\hline $\begin{array}{l}\text { Blinding of outcome as- } \\
\text { sessment (detection bias) }\end{array}$ & Unclear risk & Not described \\
\hline
\end{tabular}


Wellman 1988 (Continued)

All outcomes

$\begin{array}{ll}\begin{array}{l}\text { Incomplete outcome data } \\ \text { (attrition bias) }\end{array} & \text { Low risk } \\ \text { Quote: "two patients in the treatment group were noncompliant...data of } \\ \text { these patients were not evaluated" }\end{array}$

All outcomes

these patients were not evaluated"

\begin{tabular}{lll}
\hline $\begin{array}{l}\text { Selective reporting (re- } \\
\text { porting bias) }\end{array}$ & Low risk & Expected outcomes were reported \\
\hline Other bias & Low risk & The study appears to be free of other sources of bias \\
\hline
\end{tabular}

Characteristics of excluded studies [ordered by study ID]

\begin{tabular}{|c|c|}
\hline Study & Reason for exclusion \\
\hline Anthonisen 1974 & Patients were not in remission \\
\hline Bresci 1991 & Not an RCT - alternate allocation \\
\hline Bresci 1994 & Not an RCT - alternate allocation \\
\hline Brignola 1992 & Treatment duration $<6$ months ( 4 months) \\
\hline Camma 1997 & Not an RCT - systematic review \\
\hline Ewe 1976 & Study compared sulphasalazine to placebo, not 5-ASA to placebo or sulphasalazine \\
\hline Hanauer 1993 & Not an RCT - clinical trial \\
\hline Lennard-Jones 1977 & $\begin{array}{l}\text { Wrong comparator - study compared sulphasalazine to placebo, not 5-ASA to placebo or sul- } \\
\text { phasalazine }\end{array}$ \\
\hline Lichtenstein 2009 & Not an RCT: open-label, compassionate-use, pre-marketing clinical trial \\
\hline Luthra 2002 & This paper comments on the Mahmud 2001 study \\
\hline Malchow 1981 & $\begin{array}{l}\text { Wrong comparator - study compared sulphasalazine to placebo, not 5-ASA to placebo or sul- } \\
\text { phasalazine }\end{array}$ \\
\hline Malchow 1984 & $\begin{array}{l}\text { Wrong comparator: study compared sulphasalazine to placebo, not 5-ASA to placebo or sul- } \\
\text { phasalazine }\end{array}$ \\
\hline Nakshabendi 1992 & Not an RCT - retrospective cohort study \\
\hline Schreiber 1994 & Wrong comparator - study compared 5-ASA to 4-ASA, not 5-ASA to placebo or sulphasalazine \\
\hline Summers 1979 & $\begin{array}{l}\text { Wrong comparator: study compared sulphasazline to placebo, not 5-ASA to placebo or 5-ASA to } \\
\text { sulphasalazine }\end{array}$ \\
\hline
\end{tabular}

\section{DATA AND ANALYSES}


Comparison 1. 5-ASA compared to placebo

\begin{tabular}{|c|c|c|c|c|}
\hline Outcome or subgroup title & No. of studies & $\begin{array}{l}\text { No. of partici- } \\
\text { pants }\end{array}$ & Statistical method & Effect size \\
\hline $\begin{array}{l}1 \text { Relapse, drop-outs classed as } \\
\text { relapse, grouped by length of fol- } \\
\text { low-up }\end{array}$ & 12 & & Risk Ratio (M-H, Fixed, 95\% Cl) & Subtotals only \\
\hline 1.112 months & 11 & 2014 & Risk Ratio (M-H, Fixed, 95\% Cl) & $0.98[0.91,1.07]$ \\
\hline 1.224 months & 1 & 161 & Risk Ratio (M-H, Fixed, 95\% Cl) & $0.99[0.80,1.23]$ \\
\hline 1.3 Pediatric & 1 & 132 & Risk Ratio (M-H, Fixed, 95\% Cl) & $1.07[0.86,1.33]$ \\
\hline $\begin{array}{l}2 \text { Sensitivity analysis - Relapse, } \\
\text { drop-outs classed as relapse, } \\
\text { grouped by length of follow-up, } \\
\text { random effects }\end{array}$ & 12 & & $\begin{array}{l}\text { Risk Ratio (M-H, Random, 95\% } \\
\mathrm{CI})\end{array}$ & Subtotals only \\
\hline 2.112 months & 11 & 2014 & $\begin{array}{l}\text { Risk Ratio (M-H, Random, 95\% } \\
\mathrm{Cl} \text { ) }\end{array}$ & $0.98[0.88,1.08]$ \\
\hline 2.224 months & 1 & 161 & $\begin{array}{l}\text { Risk Ratio (M-H, Random, 95\% } \\
\mathrm{Cl})\end{array}$ & $0.99[0.80,1.23]$ \\
\hline 2.3 Pediatric & 1 & 132 & $\begin{array}{l}\text { Risk Ratio (M-H, Random, 95\% } \\
\mathrm{Cl} \text { ) }\end{array}$ & $1.07[0.86,1.33]$ \\
\hline $\begin{array}{l}3 \text { Sensitivity analysis - Relapse, } \\
\text { drop-outs ignored, grouped by } \\
\text { length of follow-up }\end{array}$ & 12 & & Risk Ratio (M-H, Fixed, 95\% Cl) & Subtotals only \\
\hline 3.112 Months & 10 & 1438 & Risk Ratio (M-H, Fixed, 95\% Cl) & $0.90[0.79,1.01]$ \\
\hline 3.224 Months & 1 & 119 & Risk Ratio (M-H, Fixed, 95\% Cl) & $0.94[0.68,1.29]$ \\
\hline 3.3 Pediatric & 1 & 102 & Risk Ratio (M-H, Fixed, 95\% Cl) & $0.97[0.72,1.31]$ \\
\hline $\begin{array}{l}4 \text { Sensitivity analysis - Relapse, } \\
\text { drop-outs ignored, grouped by } \\
\text { length of follow-up, random ef- } \\
\text { fects }\end{array}$ & 12 & & $\begin{array}{l}\text { Risk Ratio (M-H, Random, 95\% } \\
\mathrm{Cl})\end{array}$ & Subtotals only \\
\hline 4.112 Months & 10 & 1438 & $\begin{array}{l}\text { Risk Ratio (M-H, Random, 95\% } \\
\mathrm{Cl})\end{array}$ & $0.89[0.76,1.05]$ \\
\hline 4.224 Months & 1 & 119 & $\begin{array}{l}\text { Risk Ratio (M-H, Random, 95\% } \\
\mathrm{Cl} \text { ) }\end{array}$ & $0.94[0.68,1.29]$ \\
\hline 4.3 Pediatric & 1 & 102 & $\begin{array}{l}\text { Risk Ratio (M-H, Random, 95\% } \\
\mathrm{Cl} \text { ) }\end{array}$ & $0.97[0.72,1.31]$ \\
\hline 5 Adverse events & 10 & 1814 & Risk Ratio (M-H, Fixed, 95\% Cl) & $1.05[0.95,1.17]$ \\
\hline $\begin{array}{l}6 \text { Withdrawals due to adverse } \\
\text { events }\end{array}$ & 10 & 1833 & Risk Ratio (M-H, Fixed, 95\% Cl) & $1.11[0.88,1.38]$ \\
\hline
\end{tabular}




\begin{tabular}{lllll}
\hline Outcome or subgroup title & No. of studies & $\begin{array}{l}\text { No. of partici- } \\
\text { pants }\end{array}$ & Statistical method & Effect size \\
\hline 7 Serious adverse events & 3 & 576 & Risk Ratio (M-H, Fixed, 95\% Cl) & $1.43[0.24,8.44]$ \\
\hline $\begin{array}{l}\text { 8 Relapse, drop-outs classed as } \\
\text { relapse, grouped by length of fol- } \\
\text { low-up }\end{array}$ & 11 & 2014 & Odds Ratio (M-H, Fixed, 95\% Cl) & $0.97[0.81,1.16]$ \\
\hline
\end{tabular}

Analysis 1.1. Comparison 15-ASA compared to placebo, Outcome 1 Relapse, drop-outs classed as relapse, grouped by length of follow-up.

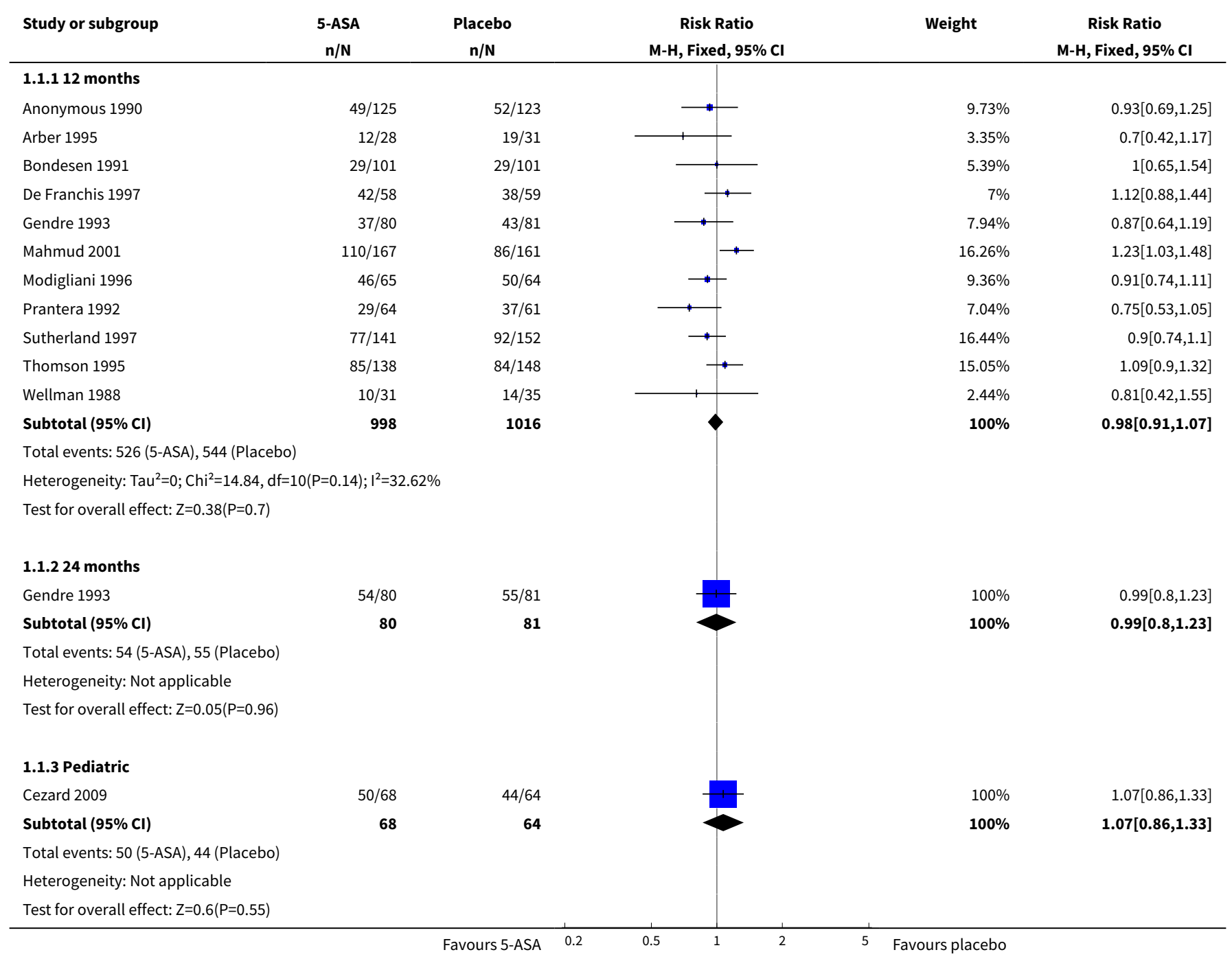


Analysis 1.2. Comparison 1 5-ASA compared to placebo, Outcome 2 Sensitivity analysis - Relapse, drop-outs classed as relapse, grouped by length of follow-up, random effects.

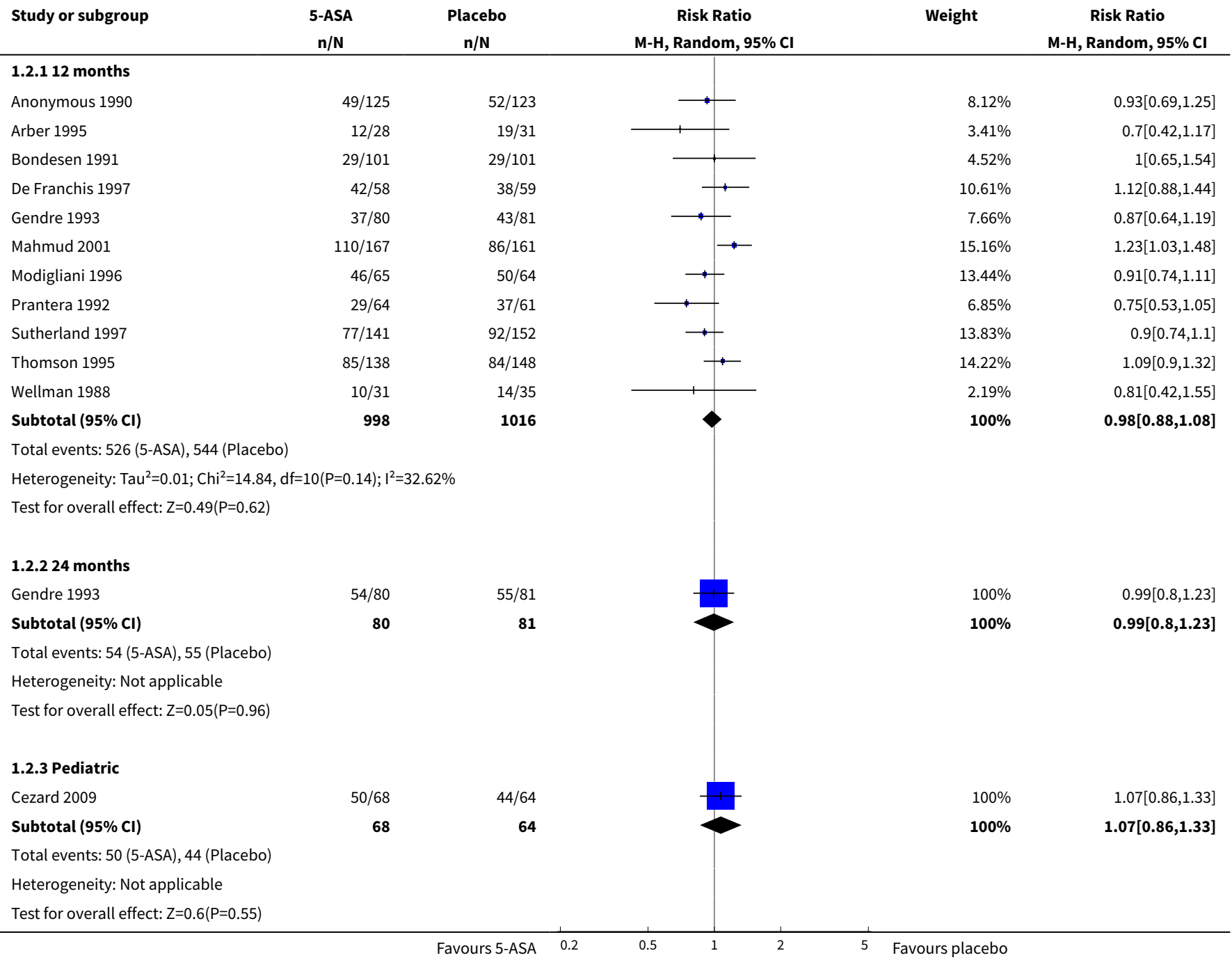

Analysis 1.3. Comparison 1 5-ASA compared to placebo, Outcome 3 Sensitivity analysis - Relapse, drop-outs ignored, grouped by length of follow-up.

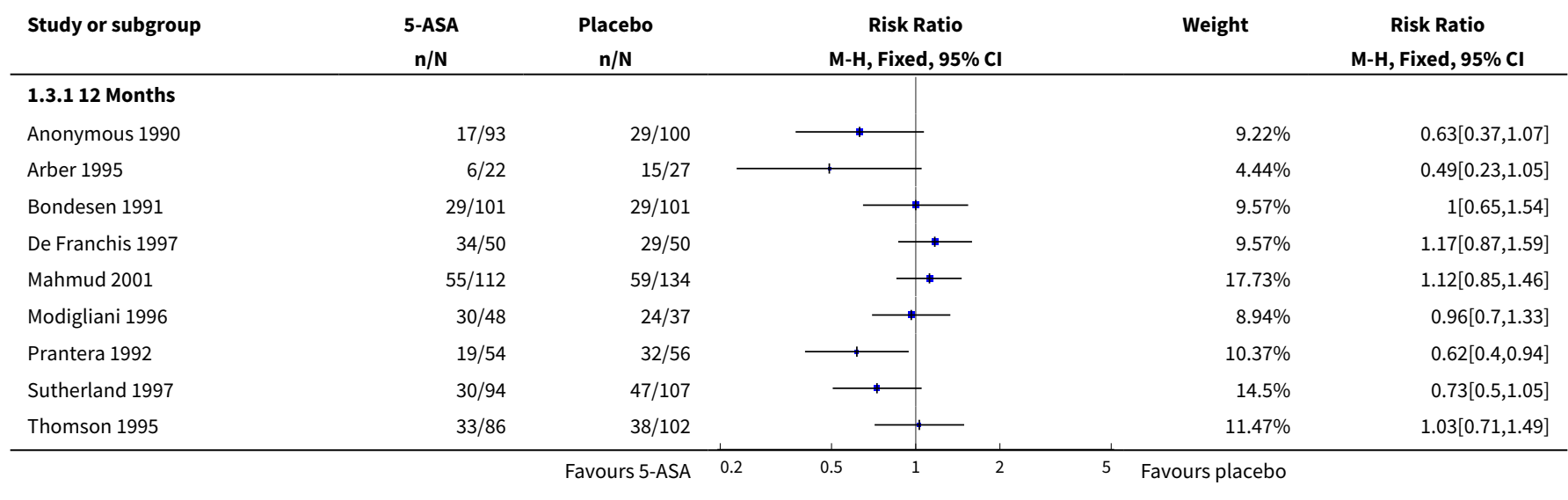




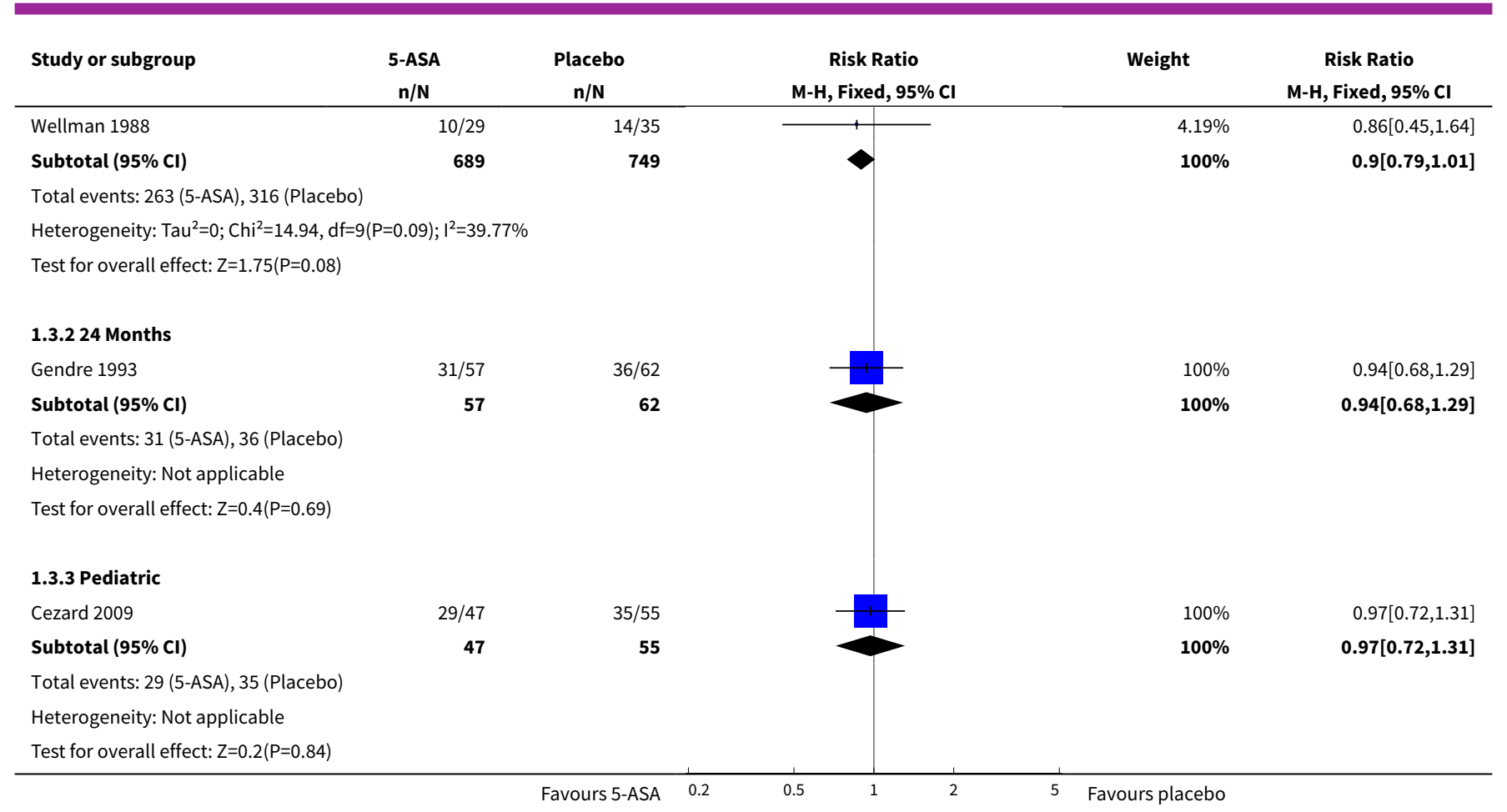

Analysis 1.4. Comparison 1 5-ASA compared to placebo, Outcome 4 Sensitivity analysis - Relapse, drop-outs ignored, grouped by length of follow-up, random effects.

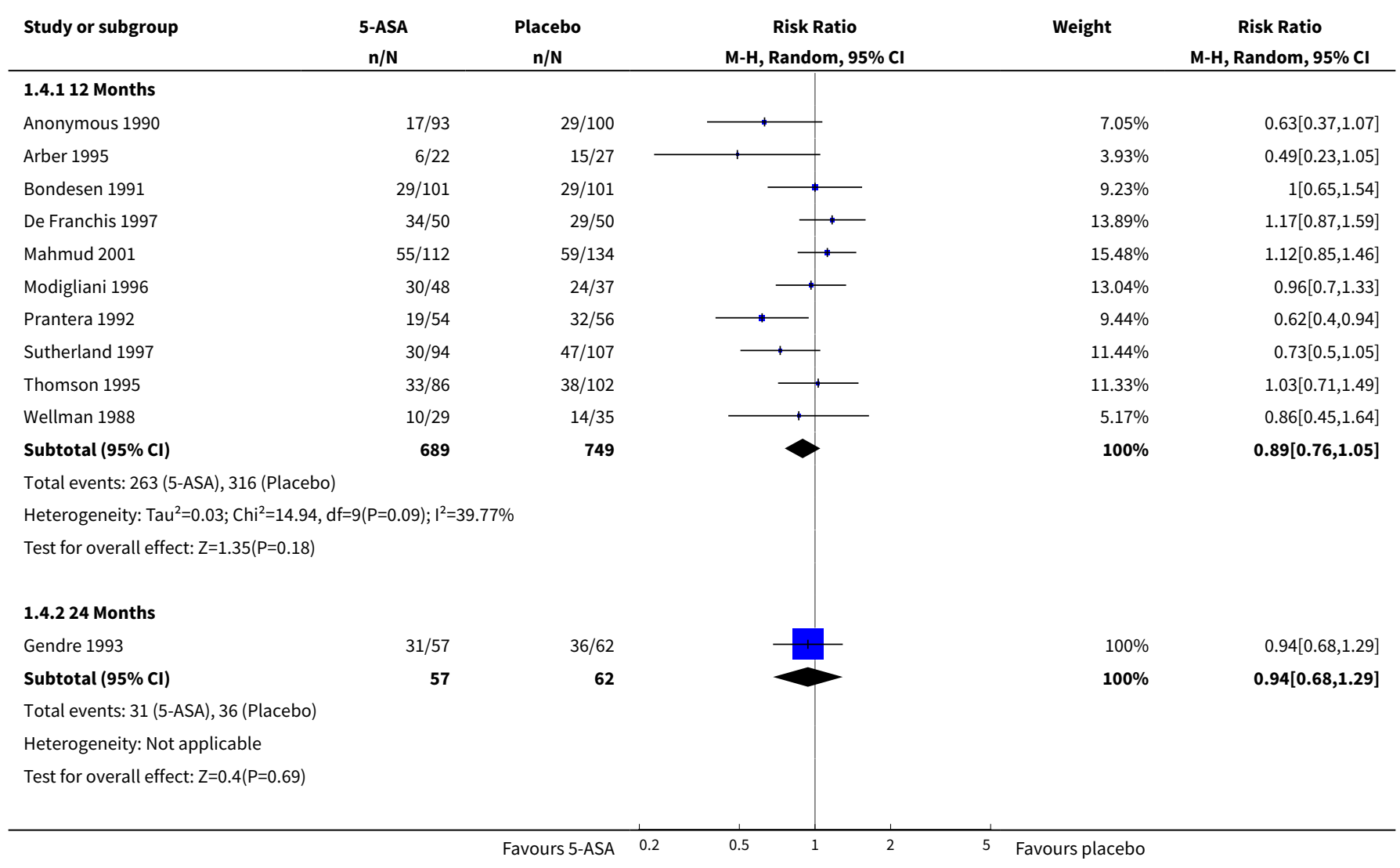




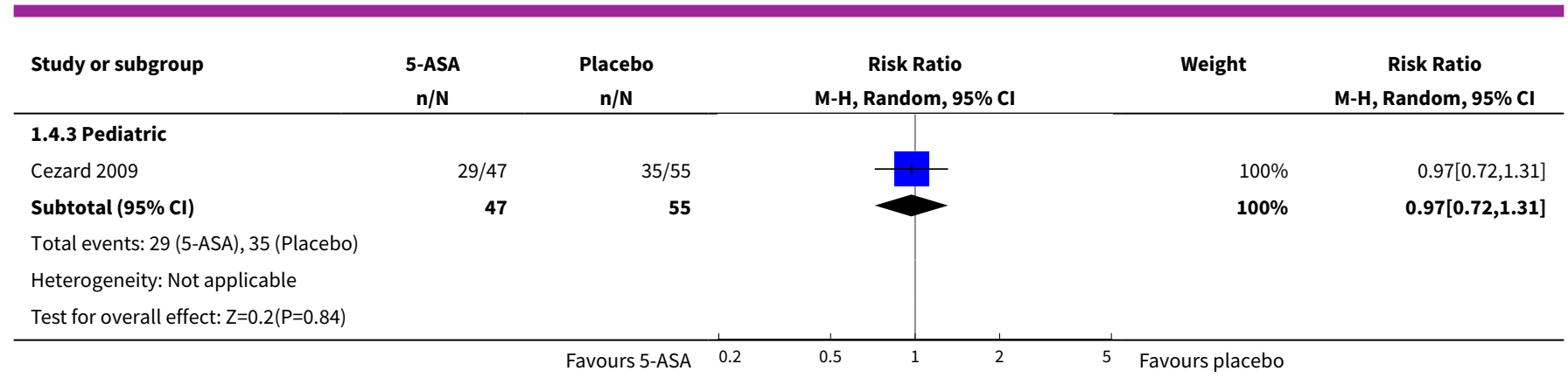

Analysis 1.5. Comparison 1 5-ASA compared to placebo, Outcome 5 Adverse events.

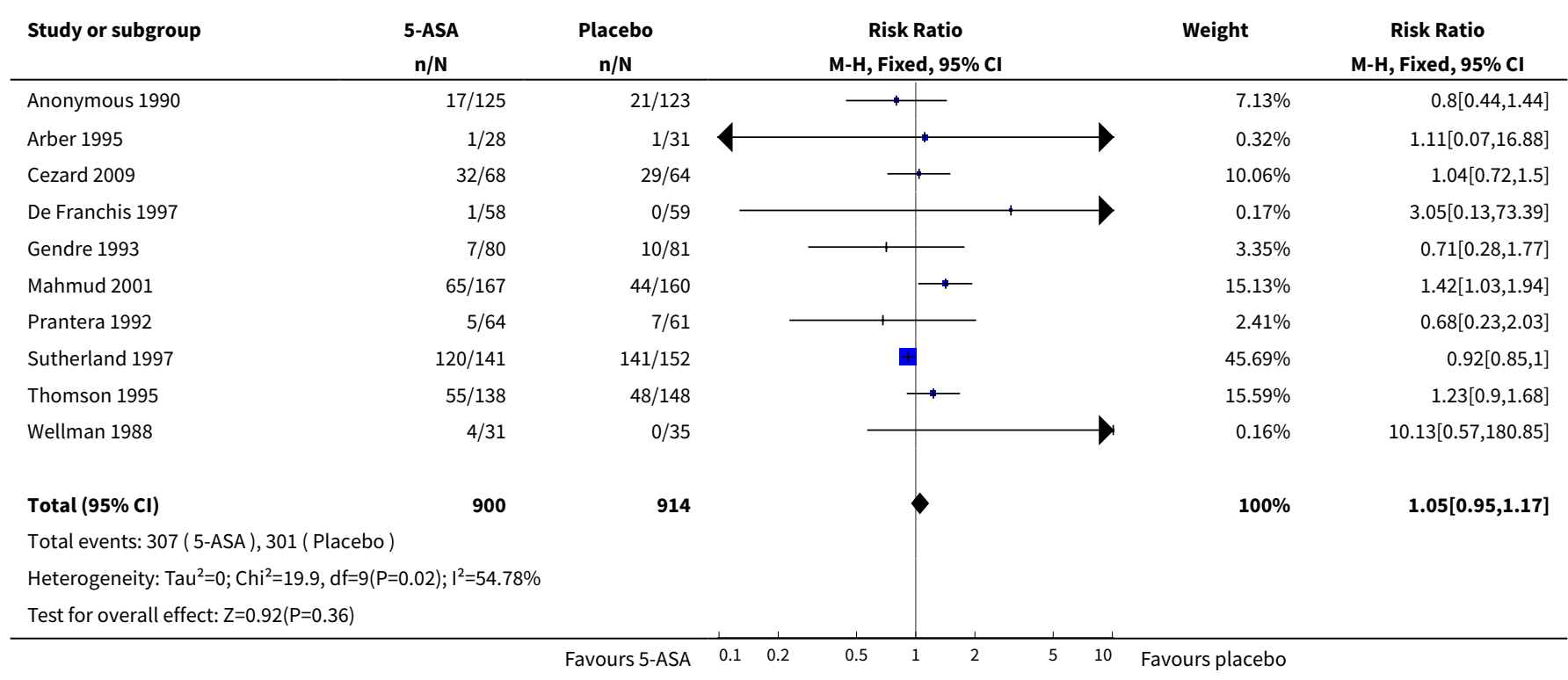

Analysis 1.6. Comparison 1 5-ASA compared to placebo, Outcome 6 Withdrawals due to adverse events.

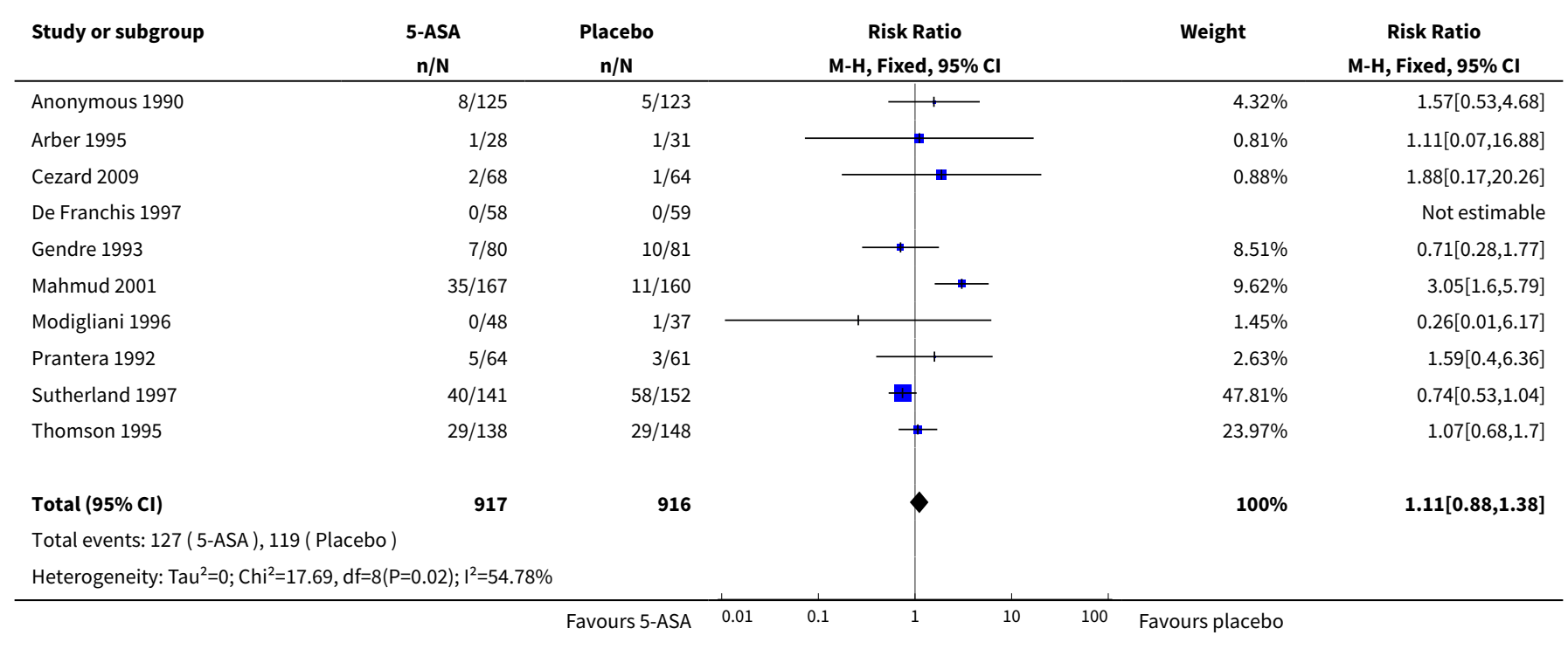




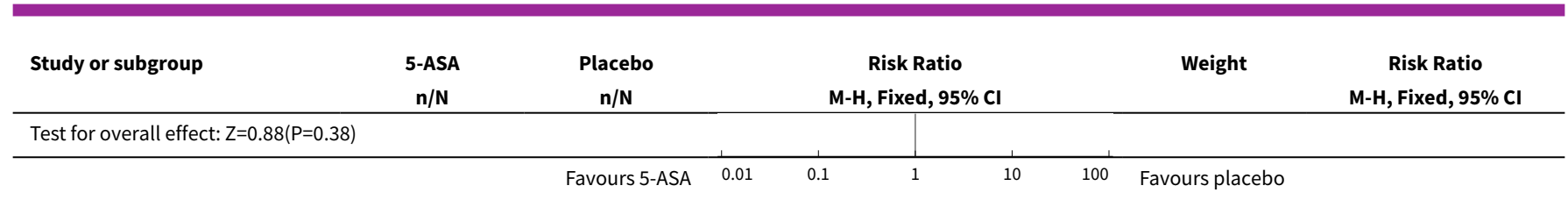

Analysis 1.7. Comparison 1 5-ASA compared to placebo, Outcome 7 Serious adverse events.

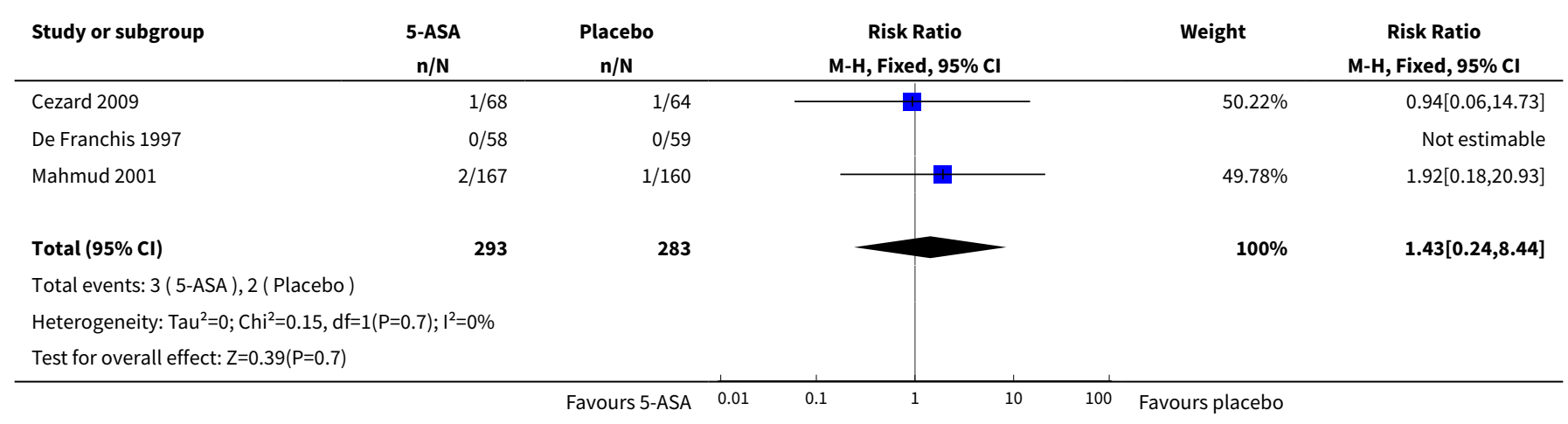

Analysis 1.8. Comparison 1 5-ASA compared to placebo, Outcome 8 Relapse, drop-outs classed as relapse, grouped by length of follow-up.

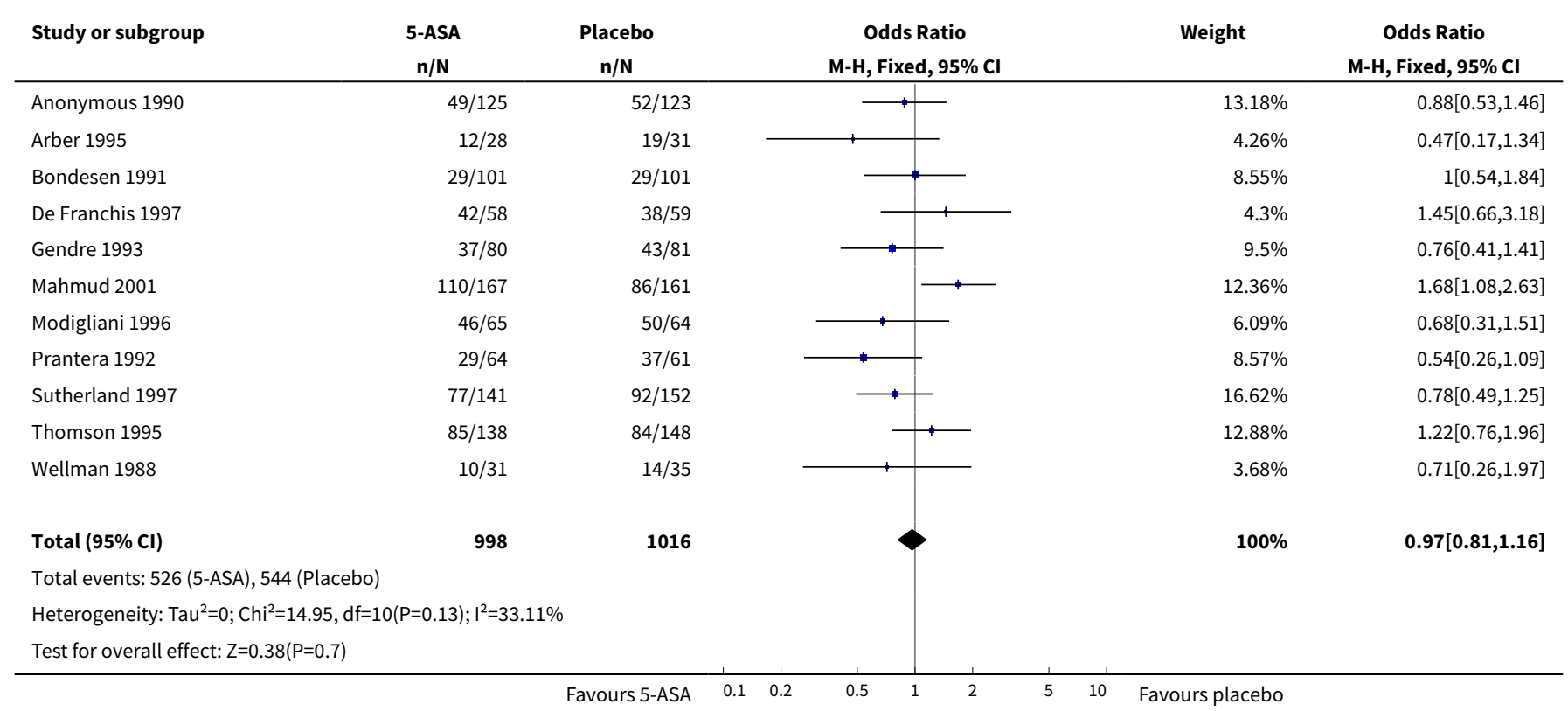

\section{ADDITIONAL TABLES}

Table 1. Randomised patients with unknown outcome

\begin{tabular}{llll}
\hline Study & Total Unknown - $n(\%)$ & 5-ASA unknown - n(\%) & Placebo unknown - n(\%) \\
\hline
\end{tabular}


Table 1. Randomised patients with unknown outcome (Continued)

\begin{tabular}{|c|c|c|c|}
\hline Anonymous 1990 & $55(22 \%)$ & $23(19 \%)$ & $32(26 \%)$ \\
\hline Arber 1995 & $10(17 \%)$ & $6(21 \%)$ & $4(13 \%)$ \\
\hline Cezard 2009 & $30(23 \%)$ & $21(31 \%)$ & $9(14 \%)$ \\
\hline De Franchis 1997 & $17(14 \%)$ & $8(14 \%)$ & $9(15 \%)$ \\
\hline Gendre 1993 (Eng) & $42(26 \%)$ & $23(29 \%)$ & $19(23 \%)$ \\
\hline Mahmud 2001 & $82(25 \%)$ & $55(33 \%)$ & $27(17 \%)$ \\
\hline Modigliani 1996 & $44(34 \%)$ & $17(26 \%)$ & $27(42 \%)$ \\
\hline Prantera 1992 & $15(12 \%)$ & $10(16 \%)$ & $5(8 \%)$ \\
\hline Sutherland 1997 & $92(31 \%)$ & $47(33 \%)$ & $45(30 \%)$ \\
\hline Thompson 1995 & $98(34 \%)$ & $52(38 \%)$ & $46(31 \%)$ \\
\hline Wellman 1988 & $2(3 \%)$ & $2(6 \%)$ & $0(0 \%)$ \\
\hline
\end{tabular}

\section{AP PE N DICES}

\section{Appendix 1. MEDLINE, EMBASE, CENTRAL and Cochrane IBD Specialized Register Search Strategies MEDLINE}

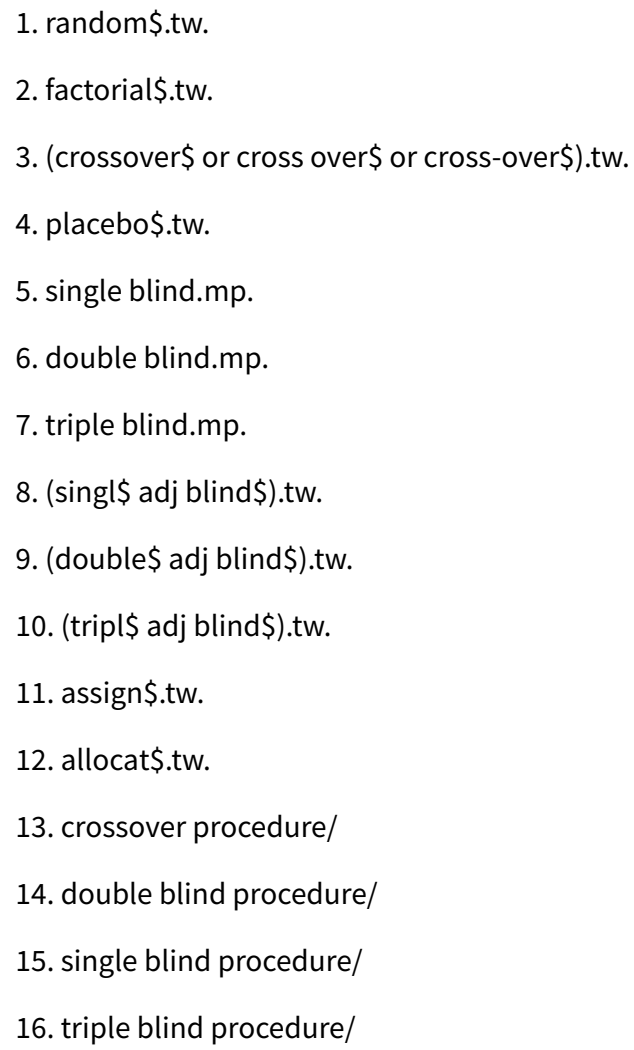

1. random\$.tw.

2. factorial\$.tw.

3. (crossover\$ or cross over\$ or cross-over\$).tw.

4. placebo\$.tw.

5. single blind.mp.

6. double blind.mp.

7. triple blind.mp.

8. (singl\$ adj blind\$).tw.

9. (double\$ adj blind\$).tw.

10. (tripl\$ adj blind\$).tw.

11. assign\$.tw.

12. allocat\$.tw.

13. crossover procedure/

14. double blind procedure/

15. single blind procedure/

16. triple blind procedure/ 
17. randomized controlled trial/

18. or/1-17

19. (exp animal/ or animal.hw. or nonhuman/) not (exp human/ or human cell/ or (human or humans).ti.)

20. 18 not 19

21. (crohn).mp.

22. exp Crohn disease/

23. ileitis.mp.

24. (inflammatory bowel disease* or IBD).mp.

25. or/21-24

26. 20 and 25

27. 5-aminosalicylic acid.mp.

28. 5-ASA.mp.

29. Mesalazine.mp. or mesalamine.mp.

30. Sulfasalazine.mp.

31. balsalazide.mp.

32. osalazine.mp.

33. (aminosalicylic or aminosalicylate).mp.

34. or/26-33

35. 26 and 34

EMBASE

1. random\$.tw.

2. factorial\$.tw.

3. (crossover\$ or cross over\$ or cross-over\$).tw.

4. placebo\$.tw.

5. single blind.mp.

6. double blind.mp.

7. triple blind.mp.

8. (singl\$ adj blind\$).tw.

9. (double\$ adj blind\$).tw.

10. (tripl\$ adj blind\$).tw.

11. assign\$.tw.

12. allocat\$.tw.

13. crossover procedure/

14. double blind procedure/

15. single blind procedure/

Oral 5-aminosalicylic acid for maintenance of medically-induced remission in Crohn's disease (Review) 
16. triple blind procedure/

17. randomized controlled trial/

18. or/1-17

19. (exp animal/ or animal.hw. or nonhuman/) not (exp human/ or human cell/ or (human or humans).ti.)

20. 18 not 19

21. (crohn).mp.

22. exp Crohn disease/

23. ileitis.mp.

24. (inflammatory bowel disease* or IBD).mp.

25. or/21-24

26. 20 and 25

27. 5-aminosalicylic acid.mp.

28. 5-ASA.mp.

29. Mesalazine.mp. or mesalamine.mp.

30. Sulfasalazine.mp.

31. balsalazide.mp.

32. osalazine.mp.

33. (aminosalicylic or aminosalicylate).mp.

34. or/26-33

35. 26 and 34

CENTRAL

\#1 MeSH descriptor: [Crohn Disease] explode all trees

\#2 Crohn

\#3 ileitis

\#4 inflammatory bowel disease

\#5 IBD

\#6 \#1 or \#2 or \#3 or \#4 or \#5

\#7 (5-aminosalicylic acid) OR (5-ASA) OR (mesalazine) OR (mesalamine) OR (sulfasalazine) OR (balsalazide) OR (osalazine) OR (aminosalicylic) OR (aminosalicylate)

\#8 \#6 and \#7

\section{Cochrane IBD Group Specialized Register}

1. (Crohn OR ileitis OR inflammatory bowel disease OR IBD) (ti/ab)

2. (5-aminosalicylic acid) OR (5-ASA) OR (mesalazine) OR (mesalamine) OR (sulfasalazine) OR (balsalazide) OR (osalazine) OR (aminosalicylic) OR (aminosalicylate)

3. 1 AND 2

Oral 5-aminosalicylic acid for maintenance of medically-induced remission in Crohn's disease (Review) 
WHAT'S NEW

\begin{tabular}{lll}
\hline Date & Event & Description \\
\hline 8 June 2016 & $\begin{array}{l}\text { New citation required but conclusions } \\
\text { have not changed }\end{array}$ & $\begin{array}{l}\text { Updated review with two new authors. Conclusions did not } \\
\text { change. }\end{array}$ \\
\hline 8 June 2016 & New search has been performed & $\begin{array}{l}\text { New literature search performed on 8 June 2016. Five new stud- } \\
\text { ies were added. }\end{array}$ \\
\hline
\end{tabular}

\section{DECLARATIONS OF INTEREST}

Anthony K Akobeng: None known

Dongni Zhang: None known

Morris Gordon has received a travel grants from various companies to attend scientific meetings to present results or chair sessions. These companies have had no input or involvement in any aspect of the review process during this or any previous systematic reviews carried out by Morris Gordon.

John K MacDonald: None known

\section{DIFFERENCES BETWEEN PROTOCOLANDREVIEW}

Partial funding for the Cochrane IBD Group (April 1, 2016 - March 31, 2018) has been provided by Crohn's and Colitis Canada (CCC).

\section{N D X T ERMS}

\section{Medical Subject Headings (MeSH)}

Administration, Oral; Anti-Inflammatory Agents, Non-Steroidal [ ${ }^{\star}$ administration \& dosage]; Crohn Disease [ ${ }^{*}$ prevention \& control]; Mesalamine [ ${ }^{*}$ administration \& dosage]; Remission Induction; Secondary Prevention; Sulfasalazine [administration \& dosage]

\section{MeSH check words}

Humans 